\title{
MINISTRY OF HEALTH
}

MANAGEMENT SCIENCES FOR HEALTH

KABUL, AFGHANISTAN

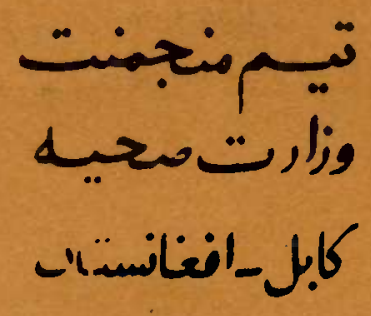

Health Administration in Afghan1stan:

Cases and Notes

by 
Health Administration in Afghanistan:

Cases and Notes

by

R. R. Srinivasa Murthy

Management Sclences for Health

Kabul

July 1978 
Contents

Page

Foreword

Note on Case Method of Teaching

Kataghan Hospital

4

IIran Hospital (A)

36

Miran Hospital (B)

51

Teaching Notes on Kataghan Hospital

78

Teaching Notes on Miran Hospital (A) and (B)

84 


\section{FOREWORD}

Health administration in Afghanistan is spearheaded by the Ministry of Public Health. Three cases on the Ministry's provincial hospitals have been brought together in this case book. Although the cases are on hospitals, their scope extends to ministry policles and procedures in budgeting and personnel. They also cover the problem of basic health center supervision, a key program for improving rural health services.

The idea of developing the case studies on management originated with the TDY report of Mr. Richard C. Owens, Jr., November 1977. The intention was to denonstrate the use of basic management techniques to Provincial Health Officers who were to meet in Kabul during the early part of 1978 . This meeting was postponed and later cancelled.

The fleld work and draft cases were done during January 1978. The drafts were enlarged, revised, and disguised during July 1978.

The Kataghan Hospital case was used on July 17, 1978 in a two and a half hour session in the pre-service training program for Basic Health Center doctors held in Kabul. According to the participants, the discussion was useful and informative. The discussion focused on civil service and

obudgeting processes and their implications to PHOs. The participants thought that the discussion set them thinking about how to manage a basic health center. The other two cases, Miran Hospital (A) and Miran Hospital (B), have not been tried. These three cases can be used in the same sequence in training health administrators, not only in Afghanistan, but in other developing countries as well. The cases can be used in training programs for ministry officials, provincial health officers and basic health center doctors. A note on the case method of teaching and teaching notes have been added to ald instructors.

Mr. Sayed Mohammad Omar Alimi has translated the caseg and notes into Dari. The Dari version of this folder is avallable from Managenent Sciences for Health, Kabul. Many members of the $M$ nagement Team and Ministry of Public Health have helped in this effort, particularly Mr. James A. Bates, Dr. Jerry M. Russe11, Mr. Henry R. Norman, Dr. Nab1 Karnyar and Mr. Sam1. Mrs. Pamela Alam, Miss Lakshmi Nagarajan and Mr. Abdul Rahman need to be specially thanked for their prompt and accurate typing. 


\section{A Note on the Case Method of Teaching}

If I 11sten, I forget;

If I see, I remember:

If I do, I know.

That is a Chinese saying. The case method of teaching is a costeffective way of bringing students close to doing.

A case is a description of an actual situation faced by a decisionnaker or manager. It describes the position as perceived by the administrator. The case writer usually has a teaching objective in mind. Such objectives may be to provide the trainees a concept, a technique, or an experience of the differences in the way different organizations handle a similar situation. To achieve his objective, the case writer prepares a case. He develops a case lead, Identifies the organization, and the decision maker. He poses the problem as percelved by the manager. The facts that are avallable to him. The manager may see only the symptoms. He may have only partial information. The real problem may be somewhere else. But the case writer presents the problem and data as perceived by the decision maker. He may also include in the case other data and per.ceptions that are necessary to handle the case discussion. It is for the trainees, who are aspiring for managerial positions, to learn to penetrate behind apparent problems and to arrive at better decisions and systems. Hence the case writer makes no attempt to narrate the problem analysis as he sees 1t. Without actually writing 1t, he could use the discrepancy bet-ween the way he and the administrator see the problem as a part of his "plot structure" of the case. The plot has to be uncovered by the discussants of the case. The foy of learning is in the classroom when the participants as a group peel out the layers of facts and hit on the real problem. The correct identification of a problem is often a major achievement.

The identification of a problem does not mean that it has a unique solution. There is usually more than one way of handling an administrative issue depending on one's personality and judgement of the situation. By this token, however, one cannot accept any and every solution. Many approaches do not make use of all the data. Some may disregard important facts, or give undue importance to peripheral problems or data. The instructor helps participants to distinguish the better approaches to admin". istrative problems from the inferior ones. He develops in the participants an ability to sift through facts and opinions and to arrive at better ways of handling situations. Very few persons can tackle a wide range of facts, opinions, uncertainty and personalities and arrive at an insightful solution that encompasses a maximum of the perspectives, priorities, and data. Even the instructor often benefits from the concerns, perspectives and insights of the participants. He often finds new ways of looking at the problem or new arguments in favor or against a solution. The case method is a valuable nedium for these objectives. 
A case should pitch at the level where participants find the problem puzzling and challenging but not incomprehensible. All participants do not have the same insight. They have different perspectives. Some are ahead. The instructor should generate discussion among participants. Some are lagging. Because the case method is participative, they learn from each other. The instructor can feel the pulse and channel the discussion. Particlpants develop a shared way of doing things and learn to communicate to each other. Mistakes in approaches can be corrected in the classroom at little cost. Attitudes can be built that are appropriate for administrator

The case method challenges the instructor and the participants to address themselves to difficult and practical problems in the cultural context and in the real world conditions of personalities, uncertainty and incomplete information. It forces the discussion and theory to the level of absorption and applicability.

To be effective, the case method demands a lot more of thinking and preparation on the part of both the instructors and the participants than does the conventional lecture method. The following are some of the prerequisites:

(1) A good case that reflects the problems, dilemas and the perspectives of the decision maker and other actors.

(2) Thorough preparation by the participants before arriving for class discussion.

(3) The focus is on problem-solving discussions, exchange of experlences and thoughts. The instructor does not present his analysis and solutions. He should let the participants develop an approach and evolve their own solutions. The instructor has to handle the discussion carefully, pose questions, plan ideas, add facts or correct misunderstandings, generate additional perspectives, provide insights, and summartze the discussion adding, if necessary, his own thoughts.

To the extent possible the instructor should generate the answers from the group than present them himself. For, the end product of case-based teaching is more than a knowledge of techniques. It should include bullding confidence, an ability to convince others, and to see relationships between any one decision, and the past and future of the organization in question. 
The case method is particularly suited for general management, marketing, human behavior and other areas requiring insights into a variety of quantitative and qualitative/human aspects of management. In certain areas such as logistics, operations research wilch are heavily quantitative, cases can be used to handle the qualitative and managerial aspects.

For a fuller discussion of the case method a good reference would be McNair's Case Method of Teaching at the Harvard Business School. B1bliographies of the case method as well as of cases can be obtained from the International Case Clearing House, Soldiers Field, Boston, Massachusetts, U.S.A. There are many such clearing houses throughout the world. In India, the Indian Institute of Management, Ahmedabad $380 \% 15$, and the Administrative Staff College of India, Bella Vista, Hyderabad, 500475 act as clearing houses for cases. These agencies produce detalled bibliographies, by subfect and by geographical area, giving names of cases and brief abstracts. They also provide master coples of cases to educational and training institutions at nominal prices. Some publishers speclalise in publishing books on Text and Cases, such as Richard D. Irwin, New York. Such case books, especially those on hospital administration, are a useful source of materials. For some books, the publishers also provide guides to instructors if a sufficient number of copies of the texts are ordered.

Although many cases are avallable, it is almost always necessary to develop case material relevant to the participants. This is one of the prime advantages of the case method. An instructor has to bring his theoritical knowledge, education and experience to the practitioners. If the immediate jobs of the participants are known, the trainers can develop relevant case material by einpirically researching into the practices, methods, attitudes, and organization of the current practitioners. It is expensive but highly credible and has a potential for high pay off. It is also time consuming. Hence, the case development effort has to be a continuous one to make the material relevant and to keep the trainers and the training at a practical level.

For short programs, in addition to developing cases, other country cases can be used. Cases can be supplemented by short role-play exercises, project work and presentation, lecture-cum-discussions, seminar workshop type sessions, problem sets and guest lectures. 
Kabul

19 اجونلاي

July 16, 1978

TO: Basic Health Center Doctors participating in the Pre-service Training Program

FROM: Professor K. R. S. Murthy Consultant

Management Team

SUBJECT: Discussions on Monday, July 17 morning session (26 Saraton)

On Monday, July 17, 1978 (26 Saraton) we will discuss the case on Kataghan Hospital. To doctors, a case is nothing new. Kataghan Hospital is a management case. It describes an actual provincial public hospital in Afghanistan. All names and places are disguised. We will discuss and see what we can learn about management from this description of an actual situation.

Read the case and the Exhibits. Bvaluate the activities of the hospital from the point of view of Dr. Hassan Ali Mahmud, Provincial Health Officer, Kataghan Province. Come prepared with your thoughts and answers to the following discussion questions:

1) What do you think of Kataghan Hospital and of Dr. Mahmud as a Provincial Health Officer? In what areas is Dr. Mahmud facing problems and why?

2) If you were the Provinciel Health Officer, how would you (i) manage the hospital and (ii) supervise the basic health centers? Whose help and cooperation would you need?

3) How can you as $\mathrm{Dr}$. Mahmud improve the working of nurses?

4) What is your evaluation of the budget proposals of Kataghan? How would you improve them? How would you get them accepted?

$$
\begin{aligned}
& \text { عنوانى د وكتوران مراكزصحى اساسى كه د دريورام } \\
& \text { تريوي قبل از اشغال وظيفه شموليت وريد هاند دريد }
\end{aligned}
$$

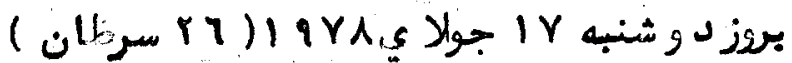

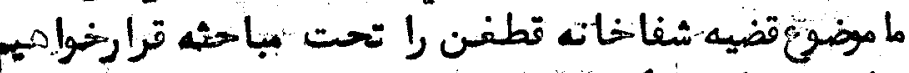

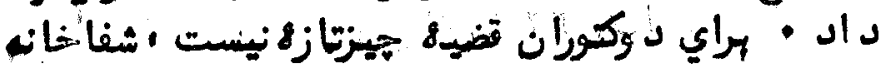

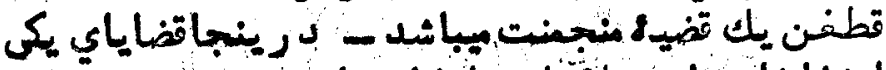

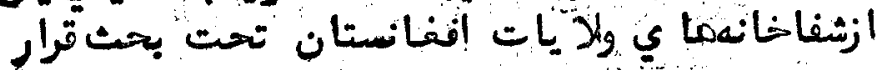

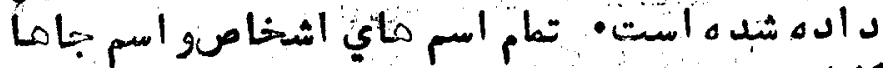

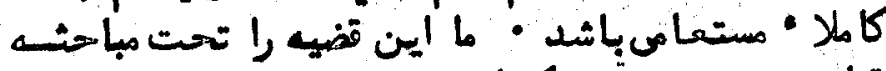

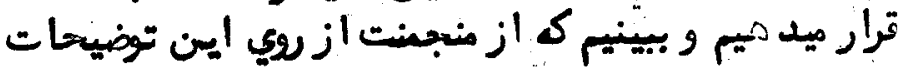

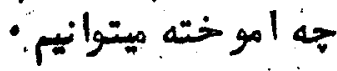

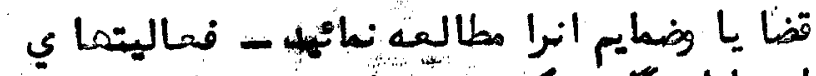

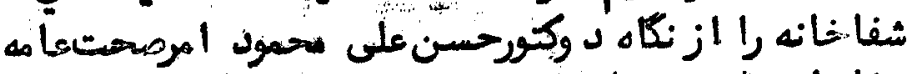

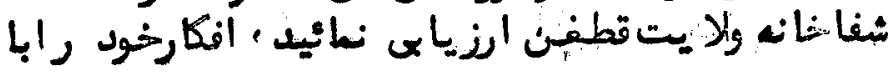

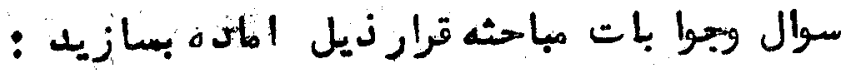

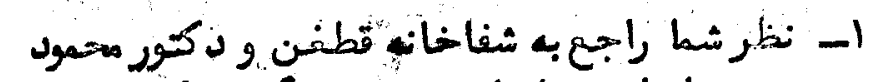

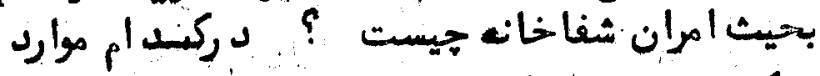

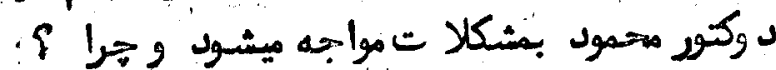

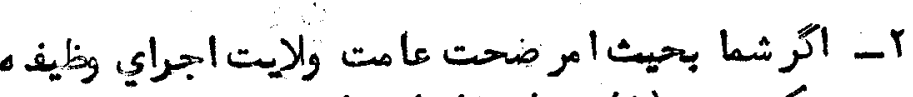

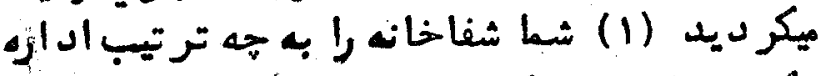

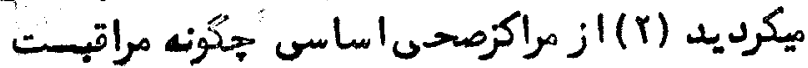

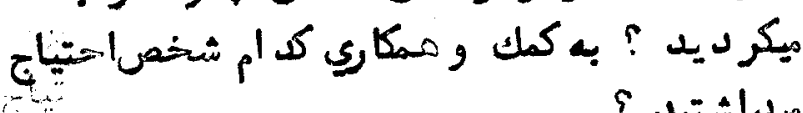
ميل اشتبلد

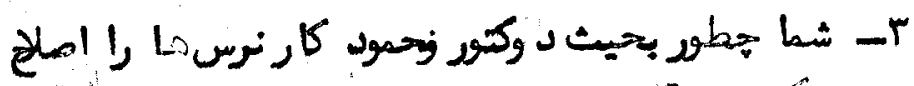
هيكر ديد

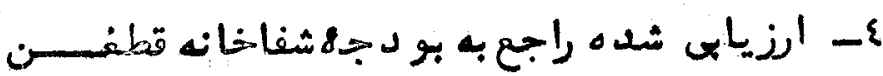

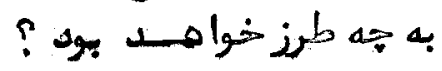

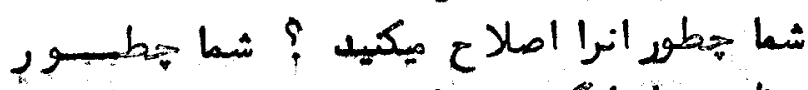


Hanagement Sciences for Health

Kabul

KATAGHAN HOSPITAL

I can stand for five hours and do surgery. I don't get tired. But all this administrative work tires me in half an hour. For the last six months I am the Provincial Health officer. Hy responsibilities are mostly administrative. There is too much work. For every little thing we have to go to the Governor. I just returned from a meeting of all the provincial offlcers held by the Governor.

Dr. Hasan AlI Mahmud was reflecting on his day's work and his experience as the Kataghan Provinclal Health officer. Before taking charge as Provincial Health officer in mid-1977, Dr. Mahmud was the Obstetrician and Gynecologist at Kataghan Hospital, one of the main hospitals in the province.

\section{Background}

The 30-bed Kataghan Hospital was one of the older hospitals and was set up in 1940. The buildings were old, the rooms were cold and inadequately heated and the furniture was in poor repair. The hospital, situated on a main street in Kataghan, consisted of three separate buildings inside two compound areas. The hospital and the buildings were owned by the Government.

\section{Organization}

The hospital had 36 permanent and 22 contract employees. Of these, eight were doctors, including the provincial health officer, a general surgeon, a pediatrician, a gynecologist/obstetriclan, two dentists and three interns. The January 1978 organization of the provincial health office, which was essentially the hospital staff, is given in Exhibit 1.

Case material of Management Sclences for Health prepared by Dr. K. R. Srinivasa Murthy. A case is not designed to 1llustrate either correct or incorrect handling of administrative problems.

$7 / 78$ 
Dr. Mahmud had many difficulties. Most of them were related to employees, the purchasing process and delays. He explained:

One difficulty I would like to discuss with the Ministry of Public Health officials is that of nurses. It is hard to keep them on their jobs. They don't stay on their jobs at night. Of course, we have someone to attend to the patients.

When the problem comes to my notice there is not much that I can do: I can mark them absent, but the nurse w111 bring a doctor's certificate and report sick. He is entitled to 20 days sick leave without doctor's verification and more on doctor's certificate depending on his length of service.

Some notes from the Civil Service Rules are given in Exhibit 2. The Kataghan Hospital had seven nurses and two female auxiliary nurse midwives (ANM). There was no head nurse. A request was included in the 1977-78 budget for a head nurse of rank 6 to do registration and medical recording. Five of the seven nurses were from Parwan. One ANM was married and lived far away while the other had been recruited recently.

\section{Nurses Work Schedule}

All nurses had to come to work during the day between 8 a.m. and 4 p.m. Three were assigned for emergency (outpatients), three to the wards, and one was assigned to the operating room. The assignment to an individual was not permanent and was changed every three months.

For night duty, a schedule was drawn up for each month. One nurse, by rotation, was free of night duty each month. The others were assigned night work in turns. The night nurse worked between $4 \mathrm{p} . \mathrm{m}$. and $8 \mathrm{a} . \mathrm{m}$. A nurse with one night's duty worked 32 hours - from 8 a.m. round the clock until $4 \mathrm{p.m}$. the next day. The schedule drawn for the month of Akrab, 1356 (October-November 1977) is given in Exhibit 3.

Nurses could exchange between them their night assignments. Or one nurse could request another to do his night work for him. Female auxiliary nurse midwives did not work at night. There was no room, according to Dr. Mahnud, where a female nurse could rest at night. No delivery cases, therefore, were hospitalized between 4 p.m. and 8 a.m.

Dr. Mahmud explained:

The long and continuous hours for the nurses is no problem. They do not usually have much work at night. They handle routine injections and dressings. If there is any emergency they send word to me and I call the night doctor on duty. If they have any emergency work I can give them a half or a full day off the next day. 
I assign a nurse in advance for duty on holidays and send coples of the order to the Governor and to the Ministry of Public Health. I think the problem of nurses not being on duty can only be handled by Kabul. I would suggest that nurses should not be posted to thelr own Province, where they can retire home or to the homes of their relatives during working hours. The local people, other than the nurses, are also untrained and indisciplined. They don't take their work serlously unless they are working for some one they know.

The nurses sald that they had no problems except that they did not have glasses or teapots. Dr. Mahmud, who was present, sald he could have got them if they had asked.

Dr. Mahmud explatned his problems in purchasing:

For even the smallest purchase $I$ have to approach the Governor. He approves and provides the authorlzation to the Finance Ministry's Mustufiat. The purchase committee, appointed by the Governor, buys and the bills are pald by the Mustufiat from the Public Health Ministry's approved budget.

It is over four months since I took charge. I have not received the authorization to spend even 1,000 Afghanis. I wrote to the Curative Department a month ago for the authorization. They have asked Administration for information. All this paperwork is irritating.

Recently we had to buy wood. It is cold. It takes us about 20 days to buy wood. We have, in fact, borrowed from the seller about 100 seers of wood, which will be just enough for three days.

\section{Purchasing}

Purchases of commoditles by government departments were subject to certaln regulations. Provincial Health officers could buy up to 1,000 Afghanis on personal authorization. Some officer exercised powers up to 5,000 Afghanis. Larger purchases had to have the authorization of the Governor or the Ministry of Public Health. Some notes on the regulations governing purchases are given in Exhibit 4.

Dr. Abdul Aziz, the surgeon at the hospital, commented on the lack of space and furniture:

I bought wooden planks recently, at my own expense, to $f$ ix on these old metal frames of cots. My patients need firm beds. It w111 take many months before the hospital can get approvals. Every year the ministry asks us for information, but we get the same budget every year. We are short of space. We need more beds and equipment. 
Dr. Mahmud was concerned about shortage of space, that three doctors were in one office, and that there was no room for the midwife to stay at night.

Budgeting Process and the 1977-78 Budgets

In response to a request by the President of Curative Medicine, the Provincial health officer had fust sent in his anticipated organization chart and budget for 1357 (1977-78). A brief note on the process of budgeting in the Ministry of Fublic Health is provided in Exhibit 5. The PHO had stated in his forwarding letter that he was having difficulty getting perwanent employees and contract employees. His letter and requests are reproduced in Exhibit 6 . In addition, the PHO had forwarded without comments the anticipated organization needs for Gandhara Woleswali Ilospital as sent to him by the Gandhara Hospital doctor.

Dr. Abdul Hakim, President of Curative Medicine, explained the action taken on the 1357 budget requests sent by Dr. Mahmud of Kataghan Province:

We do not give a uniform percentage increase to every hospital or province. We go point by point. First I see whether the anticlpated organization need is realistic or not. Is it too much or too little. Then I select the items to be included in the 1357 budget. We again have point by point discussion at the Budget Board.

of the requests sent by Dr. Mahmud, the first one of increasing the rank of the PHO from rank 3 to rank 2 is not posstble now. The second item requesting an additional nurse in rank 6 is also not realistic. We have included the upgrading of the store-keoper's rank from 7 to 6 .

The action taken by the Curative Medicine Department and the Budget Committee on the requests of the Provincial Health officer for the Kataghan Hospital along with their financial implications are given in Exhibit 7. The Budget Committee has estimated additional posts and expenses for Kataghan Hospital based on "standards" appropriate for a 30-bed hospital. These standards were judgemental and were changed in the light of finances available.

The final budget approved for the Province and the hospital would indeed be very different fron those shown in Exhtb1t 7, explained Mr. Mohamed Shafi, Director of Budgeting. It would depend on the financial allocation by the Cabinet. Another screening, with a new set of priorities would be done jointly by the. Curative Medicine Presidency in conjunction with the Budgeting Department.

Mr. Shafi explained the authority for transferring money: 
Once the budgets are approved, any reallocation from one Fasel to another (example from transportation materials - 320 to office supplies - 350) has to be approved by the Ministry of Finance. The Provincial Health officer could use the finance allocated to one moda (a sub-classification within Fasel) for another. He could use, for example, moneys llotted to books and perlodicals (317) for motor furels (311) without any permission from the Ministry of Public Health.

The Ministry of Public Health did not get the data on actual expenditure fron the hospitals.: The expenditures aggregated by hospitals and basic health centers in a province were available from the Accounts Department. The data from 1354 to 1356, along with the estimated budget for 1357 are given in Exhibit 8. Some data on actual expenditures by Kataghan Hospital are given in Exhibit 9.

The administrator of the hospital, Mr. Abdullah Naim, who had been transferred to Kataghan two months earlier, explained:

It is very difficult to get any data here. Books are not available or are incomplete. I have gone through the training given by the Ministry of Finance. Until I explained the rules and regulations, Dr. Mahmud had not approached the Ministry for authorizing him to spend up to 1,000 Afghanis.

Mr. Naim was earlier chief of services at Jamhuriat Hospital in Kabul. He had his home in Kabul and a room in Kataghan. He often commuted to Kataghan for work. Mr. Naim described hts problems:

The employees here are untrained. The Ministry of Finance recently asked all departments to introduce a card system for property accounting. Cards have arrived, but they do not know what to do with them. There are no cabinets. How can I train them without the equipment?

We are short of space. The utensils are taken out and they don't come back. There is no place to keep them. Even the medicine storage has become difficult. The World Food Program containers are lying outside in the open.

Dr. Mahmud explained:

Most of the administrator's work relates to correspondence. We receive 50 to 60 letters a week, from the Ministry, from the Basic Health Centers, and from the Provincial Governor. I tell him what to do. He sends the letters. We also redistribute letters to the health centers. 
Quite a bit of my time is taken up in legal work. Some are traffic cases. "Cases where pregnancy is to be checked.

I am a gynecologist. Women don't come to the hospital for their first delivery. We deal only with complicated cases such as a rupture of the uterus.

\section{Hospital Activities}

Avallable hospital statistics are given in Exhtbit 10. The data showed no trend. Occupancy rate was generally low and the outpatient attendances varied widely. Such data were considered generally unreliable by many provincial health officers and ministry officials.

Hospital officials estimated that about 200 patients visited the polyclinic every day. Mediclnes, Including antibiotics, were free. But the drugs standardized for a 30-bed hospital and sent once or twice a year by the Ministry were not enough for all. They were used on a firstcome first-served basis. About 80 per cent of the patients had to buy drugs from commercial pharmacists on prescriptions. Dr. Aziz commented:

Sometimes it is hard to satisfy a patient when the stocks are finished and the patient is poor and can't afford to buy the medicines. We give some pill that is available so that the patient is, satisfied.

Hospital officials felt they had enough personnel but insufficient space and equipment.

\section{Basic Health Centers}

There were 8 basic health centers in Kataghan province. These basic health centers were administered by the General Directorate of Basic Health Services in the Presidency of Preventive Medicine. The Public Health Officer was, however, responsible for supervising the basic health centers. Administratively, he reported to the President of Curative Medicine. He was expected to use the vehicle and staff for supervising the health centers. There were, of course, mobile teams of the Preventive Medicine Presidency which visited the basic health centers once or twice a year for supervision and training.

The eight basic health centers in Kataghan province were around Kataghan between 8 and 75 kilometers from the Kataghan township. While some roads were good, others were bad; the eight centers could be covered in four separate trips, two of eight hours each, one of six hours and the other 10 hours. These durations provide for travelling and two hours at each center.

Available data on the elght centers are given in Exhibit 11. Dr. Wahmud had visited only Foladi once during his six months as PHO. 
Exhibit 1

Kataghan Hospital

Organization of Kataghan Public Hospital

\begin{tabular}{|c|c|c|c|c|c|c|c|}
\hline Personnel & Rank & $\begin{array}{l}\text { No. of } \\
\text { Persons }\end{array}$ & $\begin{array}{l}\text { Total } \\
\text { Annual } \\
\text { Salary } \\
\text { of all } \\
\text { in Afs }\end{array}$ & Personnel & Rank & $\begin{array}{l}\text { No. of } \\
\text { Persons }\end{array}$ & $\begin{array}{l}\text { Total } \\
\text { Annual } \\
\text { Salary } \\
\text { of all } \\
\text { in Afs }\end{array}$ \\
\hline \multicolumn{8}{|l|}{ Employees: } \\
\hline $\begin{array}{l}\text { Doctors } \\
" 1 \\
"(x-r a y) \\
" 1\end{array}$ & $\begin{array}{l}3 \\
4 \\
5 \\
6 \\
8\end{array}$ & $\begin{array}{l}1 \\
2 \\
1 \\
3 \\
1 \\
\end{array}$ & $\begin{array}{l}51,000 \\
73,200 \\
33,000 \\
90,000 \\
22,800 \\
\end{array}$ & $\begin{array}{cc}\text { Admin. } & \text { Director } \\
" 1 & \text { Worker } \\
" 1 & " 1 \\
" 1 & " 1 \\
\end{array}$ & $\begin{array}{l}5 \\
6 \\
7 \\
8 \\
9 \\
\end{array}$ & $\begin{array}{l}1 \\
1 \\
2 \\
1 \\
1 \\
\end{array}$ & $\begin{array}{l}33,000 \\
30,000 \\
52,800 \\
22,800 \\
21,000 \\
\end{array}$ \\
\hline " Subtotal & - & 8 & 270,000 & "Subtotal & - & 6 & 159,600 \\
\hline \multirow{3}{*}{ 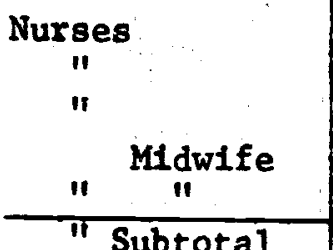 } & \multirow{2}{*}{$\begin{array}{l}6 \\
7 \\
9 \\
7 \\
8 \\
\end{array}$} & \multirow{2}{*}{$\begin{array}{l}1 \\
2 \\
3 \\
2 \\
2 \\
\end{array}$} & \multirow{3}{*}{$\begin{array}{l}30,000 \\
52,800 \\
63,000 \\
52,800 \\
45,600 \\
244,200 \\
\end{array}$} & Total Employees & - & 36 & 945,600 \\
\hline & & & & $\begin{array}{l}\text { Contractors: } \\
\text { Property Keeper }\end{array}$ & \multirow{3}{*}{$\begin{array}{l}6 \\
7 \\
7 \\
7 \\
9 \\
10 \\
11\end{array}$} & \multirow{3}{*}{$\begin{array}{r}1 \\
1 \\
1 \\
1 \\
1 \\
2 \\
15\end{array}$} & \multirow{3}{*}{$\begin{array}{l}22,800 \\
19,200 \\
19,200 \\
19,200 \\
13,440 \\
\\
24,720 \\
169,200 \\
\end{array}$} \\
\hline & - & 10 & & \multirow{2}{*}{$\begin{array}{l}\text { Property Keeper } \\
\text { Cashier } \\
\text { Typist } \\
\text { Driver } \\
\text { Cook } \\
\text { Tallor- } \\
\text { Launderers } \\
\text { Assistance * }\end{array}$} & & & \\
\hline \multirow{2}{*}{$\begin{array}{l}\text { Compounders } \\
\text { Lab. Tech. } \\
\text { Mechanic } \\
\text { Lab. Asst. } \\
\text { Medical Recorder } \\
\text { Sanitarlans } \\
\text { Vaccinators }\end{array}$} & \multirow[t]{2}{*}{$\begin{array}{l}8 \\
7 \\
9 \\
9 \\
8 \\
8 \\
9\end{array}$} & \multirow{2}{*}{$\begin{array}{l}2 \\
2 \\
1 \\
1 \\
1 \\
2 \\
3\end{array}$} & \multirow{2}{*}{$\begin{array}{l}45,600 \\
52,800 \\
21,000 \\
21,000 \\
22,800 \\
45,600 \\
63,000\end{array}$} & & & & \\
\hline & & & & $\begin{array}{l}\text { Total Contrac- } \\
\text { tors }\end{array}$ & - & 22 & 287,760 \\
\hline \multirow[t]{3}{*}{ "Subtotal } & \multirow[t]{3}{*}{ - } & \multirow[t]{3}{*}{12} & \multirow[t]{3}{*}{271,800} & & & & \\
\hline & & & & TOTAL & - & 58 & $1,233,360$ \\
\hline & & & & Extra Payments & & & 176,000 \\
\hline
\end{tabular}

*6 untrained nurses, 2 peons, 1 cleaner, 2 guards, 1 barber, 1 gardener

1 assistant to cook and 1 assistant to launderers.

As of January 1977 (Jadi 1356) 
Exhibit 2

Kataghan Hospital

Some Notes on Civil Service Rules

Civil servants are classified Into four classes and ten grades:

Class Grade acceptance of resignation:

A Outside

Grade President

I \& II Minister's proposal, support of Counc1l of

Ministers, approval of President

B III, IV, V Minister

C VI, VII, VIII Minister

D IX, X Minister for all posts in Kabul for

professional and technical civil servants in the provinces.

Governor of Province for nor-professional

and non-technical civil servants in the

provinces.

At the time of inftial appointment, graduation from secondary education (12 years of school) is required for grade 10 and a university degree (four years) for grade 9 and one priority step.

Those with competence can, if needed, be appointed to higher grades as follows:

\section{Qualifications}

B.A. or equivalent

Licensee degree

Diploma beyond license

Masters or equivalent

Doctoral or equivalent
Years in Number of

Original Grade Higher Grades

3

3

2

2

1 up to 2

up to 4

up to 5

up to 5

up to 6

A person can, if needed, be appointed one grade higher but cannot enjoy its salary unless he attains the educational qualifications mentioned above. 
Exhibit 2

(continued)

page 2

Kataghan Hospital

\section{Salary}

Salary is paid monthly according to the salary table:

Salary Table

Salary Per Month in Afghanis

$\underline{\text { Rank }}$

$1354(1976) \quad 1356(1977)$

\section{Outside Grade}

1

2

3

4

5

6

7

8

9

10

11
10,200

5,700

4,800

3,900

2,700

2,400

2,100

1,800

1,500

1,350

1,200

1,050
10,500

6,000

5,100

4,250

3,050

2,750

2,500

2,200

1,900

1,750

1,600

1,450

\section{Supplements}

Supplements to salary are given if civil servant has a graduate document or for working under climatic or health hazards.

\section{Overtime}

Overtime at an hourly rate is paid on official days and at $1^{\frac{1}{2}}$ times the rate for work on public holidays.

The calculation for overtime is based on a 40-hour work week.

\section{Leaves}

Leave records are not kept in the Ministry in Kabul. They are handled by the department concerned.

A civil servant is entitled each year to 20 days annual leave, 20 days sick leave and 10 days emergency leave with payment. 
Exhibit 2

(continued)

page 3

Kataghan Hospital

The leave cannot be accumulated over the years.

Sick leave is accepted up to 3 days on the basis of a written notice of the staff. Sick leave for more that 3 consecutive days may be accepted on the basis of a certificate of a medical doctor.

Sick leave may be charged to other leave if it exceeds the determined period.

Once in each special term, staff may be entitled to paid leave for continued sickness resulting in inability to perform duties as follows:

Length of Service Paid Sick Leave

$\begin{array}{ll}\text { up to } 5 \text { years } & 3 \text { months } \\ 5 \text { to } 10 \text { years } & 6 \text { months } \\ \text { More than } 10 \text { year } & 1 \text { year }\end{array}$

Female civil servants are entitled to 30 days of leave before child delivery and 30 days after delivery, for a maximum of 3 times.

Absence

A civil servant is considered absent if he fails to inform in writing within 3 days of his absence. For each day of his absence, 2 days salary will be deducted.

Absence of 10 consecutive days or more will be recorded in the performance report and will not be counted in his service.

A competent officer can consider the absence as legal leave if he is convinced of the legal reasons. Such reasons have to be provided within 20 days.

If the absence of a civil servant in a year, continually or separately exceeds 20 days, this act may be considered job quitting.

If a civil servant leaves his job without a written report, three day's salary will be deducted for each day absent.

\section{Promotion}

Promotion Commissions are selected by Ministers in Kabul and by Governors in Provinces.

The Promotion Commission appointed by the Minister of Public Health handles all promotions from grade 11 to 3 . 
Exhibit 2

(continued)

page 4

Kataghan Hospital

Grade promotion is promotion to a higher grade.

Salary promotion is salary increment within the same grade.

A civil servant is entitled to grade promotion on (i) completion of the appointed term of service, (ii) suitable performance reports, and (iii) availability of post and suitability of civil servant.

If more than one candidate is entitled, promotion is based on relative quality of performance report, level of study and priority steps regarding grade, and work background.

If all qualities are equal then promotion will be on the basis of an examination.

If a civil servant is qualified for promotion but the post is not avallable, he will get one-third salary difference of the higher post compared to his present post each year.

The legal capacity of a civil servant is based on the performance report and annual report given by his superfors. The performance report is prepared at the end of promotion period and the capacity report is given at the end of each year. (The formats are given at the end of these notes. No action is taken on annual reports, but are accumulated for three yearly Promotion Evaluation).

The immediate supervisor and the one above him fill the performance forms.

Transfers

Transfers are handled by a committee appointed by the Minister.

Except under special circumstances, a civil servant cannot be transferred in a period less than a term of three years promotion.

Competent supervisors may take action on transfers in the following cases:

(i) unsuitable performance report;

(ii) concurrence of two departments and approval of both sides;

(11i) urgent need of office;

(iv) correctional transfers when the civil servant has misused or acted contrary to the prestige of his office. 
Exhibit 2

(continued)

page 5

Kataghan Hospital

Rewards and Appreciation

Appreciation Letter, Class A

This includes a one-grade promotion and given for outstanding services in extraordinary cases (For Grade 1 - six months salary)

Appreciation Letter, Class B

One year priority and two months salary with supplements, given on the proposal of the Minister or first grade supervisor and approval of the President (For Grade 1 - four months salary)

Appreciation Letter, Class C

Three months salary plus supplements. Given on the proposal of the concerned department or directly by the first class supervisor or by the Minister. 
Exhibit 2

(continued)

page 6

Kataghan Hospital

Annual Capability Report Format

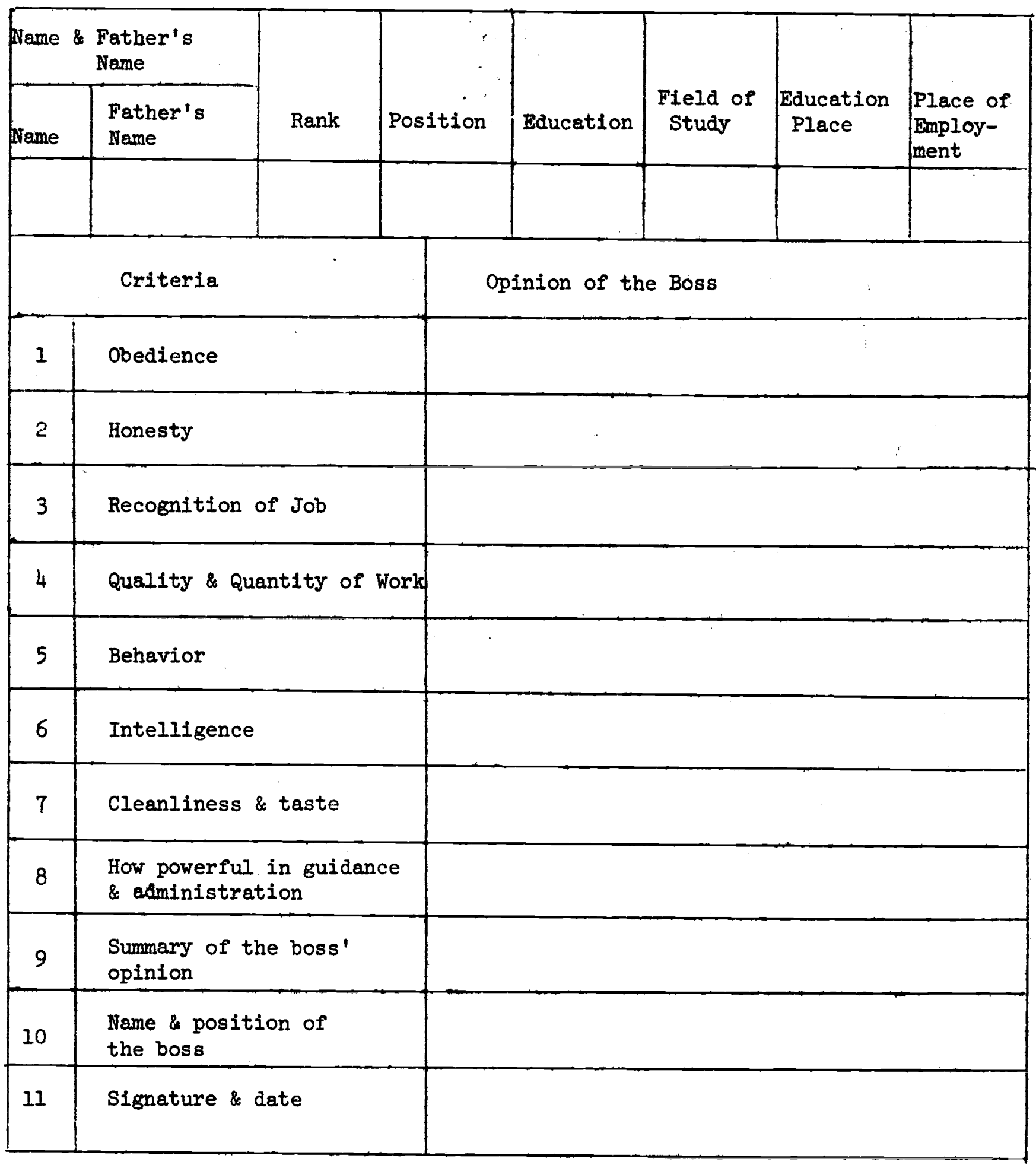


Exhibit 2

(continued)

page 7

Kataghan Hospital

Performance Report Format

(Promotion Criteria)

\begin{tabular}{|c|c|c|c|c|c|c|}
\hline & Criteria & Descrintion of Criteria & $\begin{array}{c}\text { Graded } \\
\text { 1st }\end{array}$ & $\begin{array}{l}\text { by the } \\
\text { Boss }\end{array}$ & $\begin{array}{c}\text { Graded } \\
\text { 2nd }\end{array}$ & $\begin{array}{l}\text { by the } \\
\text { oss }\end{array}$ \\
\hline & & drilueria & \begin{tabular}{|l|} 
In \\
digits \\
\end{tabular} & $\begin{array}{c}\text { In } \\
\text { writing }\end{array}$ & \begin{tabular}{|c|} 
In \\
digits \\
\end{tabular} & $\begin{array}{c}\text { in } \\
\text { writing } \\
\end{array}$ \\
\hline 1 & Obedience & $\begin{array}{l}\text { 1. To obey rules } \\
\text { 2. To obey laws }\end{array}$ & $\begin{array}{l}1 \\
2 \\
3 \\
4 \\
5 \\
\end{array}$ & & $\begin{array}{l}1 \\
2 \\
3 \\
4 \\
5\end{array}$ & \\
\hline 2 & Honesty & $\begin{array}{l}\text { 1. How honest } \\
\text { 2. How confidential (keeps secrets) }\end{array}$ & $\begin{array}{l}1 \\
2 \\
3 \\
4 \\
5\end{array}$ & & $\begin{array}{l}1 \\
2 \\
3 \\
4 \\
5\end{array}$ & \\
\hline 3 & \begin{tabular}{|l|} 
Recognition \\
of \\
Responsi- \\
bility \\
\end{tabular} & $\begin{array}{l}\text { 1. How punctual } \\
\text { 2. How much interested in doing } \\
\text { the job }\end{array}$ & $\begin{array}{l}1 \\
2 \\
3 \\
4 \\
5 \\
\end{array}$ & & $\begin{array}{l}1 \\
2 \\
3 \\
4 \\
5 \\
\end{array}$ & \\
\hline 4 & $\begin{array}{l}\text { Quality \& } \\
\text { Quantity } \\
\text { of Work }\end{array}$ & $\begin{array}{l}\text { 1. How successful in accomplish- } \\
\text { ing his job. } \\
\text { 2. How firm in his job. }\end{array}$ & $\begin{array}{l}1 \\
2 \\
3 \\
4 \\
5\end{array}$ & & $\begin{array}{l}1 \\
2 \\
3 \\
4 \\
5\end{array}$ & \\
\hline 5 & Behavior & $\begin{array}{l}\text { His attitudes \& behavior towards } \\
\text { colleagues, clients \& bosses }\end{array}$ & $\begin{array}{l}1 \\
2 \\
3 \\
4 \\
5\end{array}$ & & $\begin{array}{l}1 \\
2 \\
3 \\
4 \\
5\end{array}$ & \\
\hline 6 & $\begin{array}{l}\text { Intelli- } \\
\text { gence }\end{array}$ & $\begin{array}{l}\text { The intelligence \& knowledge } \\
\text { of the employee }\end{array}$ & $\begin{array}{l}1 \\
2 \\
3 \\
4 \\
5\end{array}$ & & $\begin{array}{l}1 \\
2 \\
3 \\
4 \\
5\end{array}$ & \\
\hline 7 & $\begin{array}{l}\text { Cleanliness } \\
\text { \& Taste }\end{array}$ & $\begin{array}{l}\text { 1. His personal \& in the office } \\
\text { cleanliness \& taste } \\
\text { 2. How well organized in the } \\
\text { office }\end{array}$ & $\begin{array}{l}1 \\
2 \\
3 \\
4 \\
5\end{array}$ & & $\begin{array}{l}1 \\
2 \\
3 \\
4 \\
5\end{array}$ & \\
\hline
\end{tabular}


Exhibit 2

(continued)

page 8

Kataghan Hospital

Continuation of

Performance Report Format

(Promotion Criteria)

\begin{tabular}{|c|c|c|c|c|c|}
\hline & Description of Criteria & $\begin{array}{c}\text { Grade } \\
\text { lst }\end{array}$ & $\begin{array}{l}\text { d by the } \\
\text { Boss }\end{array}$ & $\begin{array}{l}\text { Graded } \\
\text { 2nd } \mathrm{E}\end{array}$ & $\begin{array}{l}\text { Boss by the } \\
\text { Boss }\end{array}$ \\
\hline & & \begin{tabular}{|l|} 
in \\
digits \\
\end{tabular} & \begin{tabular}{|c|} 
in \\
writing \\
\end{tabular} & \begin{tabular}{c|} 
in \\
digits
\end{tabular} & $\begin{array}{c}\text { in } \\
\text { writing }\end{array}$ \\
\hline 8 & \begin{tabular}{l|l} 
How powerful & 1. Acceptance of responsibility \\
in guidance & 2. Power in creation \\
\& administran & 3. How powerful in coordinating \\
affairs & 4. How capable in development of \\
affairs according to the & conditions of the environment. \\
5. His succeding measures to the \\
guidance of people who are \\
under him.
\end{tabular} & $\begin{array}{l}1 \\
2 \\
3 \\
4 \\
5\end{array}$ & & $\begin{array}{l}1 \\
2 \\
3 \\
4 \\
5\end{array}$ & \\
\hline & tal number of the lst boss & Total & number $c$ & f the 2 & 2nd boss \\
\hline & erage number of the lst boss & Avera & ge number & of the & $\begin{array}{l}\text { 2nd } \\
\text { boss }\end{array}$ \\
\hline & oroval of the lst boss & Appro & val of $t h$ & e 2nd $k$ & boss \\
\hline & $\begin{array}{l}\text { ne \& Position of the lst boss } \\
\text { gnature \& date }\end{array}$ & $\begin{array}{l}\text { Name } \\
\text { Signa }\end{array}$ & $\begin{array}{l}\text { \& positic } \\
\text { ture \& de }\end{array}$ & $\begin{array}{l}\text { n of } t r \\
\text { te }\end{array}$ & $\begin{array}{l}\text { he } 2 \text { nd } \\
\text { boss }\end{array}$ \\
\hline & inion of the Promotion Committee & & & & \\
\hline & decision of the bis boss & & & & \\
\hline
\end{tabular}

Notes: - Be honest and neutral

- Grade 1: if satisfactory, cannot be improved

2: if satisfactory, but can be improved

3: if average

4: if high

5: if excellent

- For rank and salary promotion total average of 4 is needed. Also, on criteria 1 (Obedience) and 2 (Honesty) the grade should be at least 4.

- Criteria inapplicable to an employee are excluded from the average. 


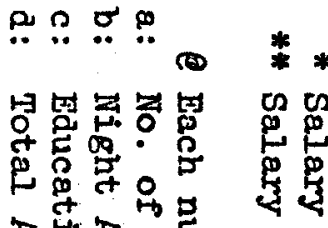

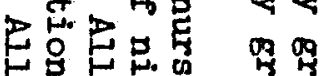

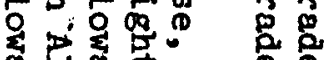

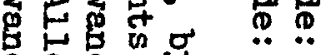

员罂

H.

98

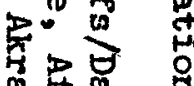

点象

도용 행

空



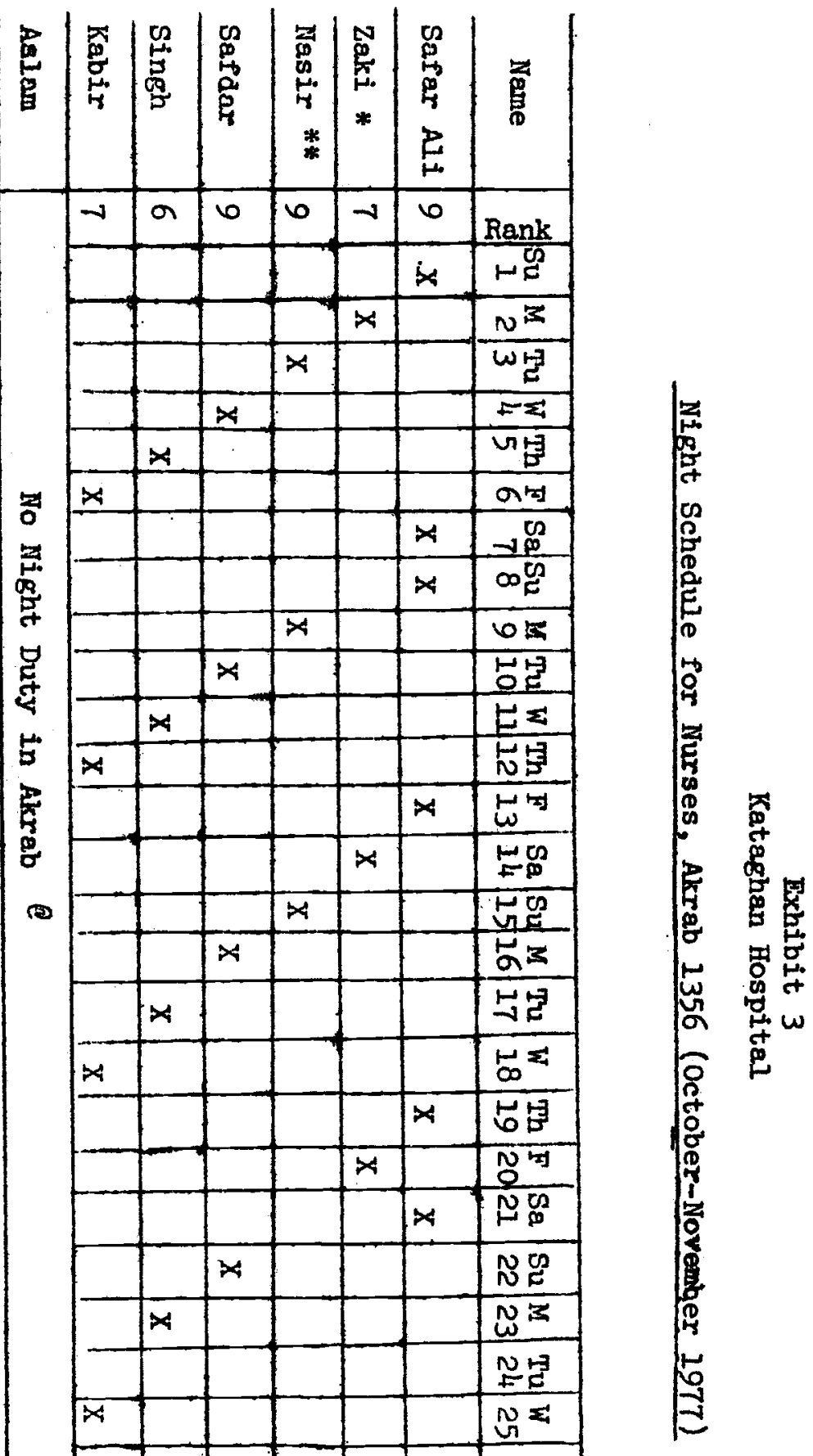




\begin{abstract}
Exhibit 4
Kataghan Hospital

Some Notes on the Regulations Governing Purchase of Commodities by State Department
\end{abstract}

General Provisions

- Approving officer determines the need to purchase.

- Comitments can be made only if requisite budgetary allocations are available.

- Preference is given to national products (up to 15 per cent in price/ quality) and to government sources.

- Transactions are subject to Commerce Law.

Miscellaneous Purchases (up to 50,000 Afghanis)

- Miscellaneous purchases are made through bargaining.

- Only one member of the Purchase Committee can buy.

- Purchase Committee, whose members are designated each quarter by the first degree approving officer, can buy comodities up to 50,000 Afghanis.

- If the amount is less than 1,000 Afghanis, the seller's bill and certification by a member is complete documentation.

- If the amount is between 1,000 and 50,000 Afghanis, the Purchase Committee has to obtain bids from three places; the seller's bill and certification by the Purchase Committee is complete documentation.

Ma,jor Purchases (More than 50,000 Afghnis)

- Major purchases are made through bidding sessions.

- The concerned office can specify the conditions for bidding. They should include specifications, price, payment terms and conditions, place and time of delivery, security required for bidding and for concluding contract, compensition for damages due to late delivery (mode of payment or replacenent).

- Advertisements calling biddres have to be placed (at least 3 times repeatedly or alternately) in one high circulation daily if the amount is between 50,000 and 100,000 Afghanis, and in two such dailies from the Capital and in Radio Afghanistan if the amount is more than 100,000 Afghanis.

- The form of bidding can be open (i.e. quotations opened in the presence of bididers who can revise their tenders) or it can be closed. The bidding comission appointed for the purpose has to conduct the bidaing according to official guidelines, and submit a recommendation to the approving officer before detailed contracts can be signea. 


\author{
Exhibit 4 \\ (continued) \\ Kataghan Hospital
}

page 2

Some Notes on the Regulations Governing Purchase of Commodities by State Department

\title{
Miscellaneous Provisions (Mmergency Purchases)
}

- Purchase of wheat, sugar, petroleum products and such other commodities is not subject to the regulations mentioned above.

- Emergency purchases such as those required to prevent machinery from becoming idle, or those to protect human life, or fight fire or destruction, are not subject to these regulations. Confirmation. and approval for these purchases can be obtained before or after the purchase. 
Exhibit 5

Kataghan Hospital

\section{A Brief Note on the Budgeting Process}

The budgeting exercise starts towarls the end of the third quarter when the Minister of Finance writes to the Minister of Public Health requesting estimates of the budget for the next year. At this time, the financial position of the Government is not yet clear and hence no guidelines are provided to the Ministry of Public Health. The President of Administration in the Ministry writes to the heads of ail departments, such as the curative and preventive departments, to send their budget estimates.

The President of the Curative Medicine Department writes to the various heads, including Provincial Health Officers, to send their budget estimates. No format is used. One was tried, but it was found difficult to use and was, therefore, discontinued. The requests from the Provincial Health officers, therefore, take the form of a long letter listing out the needs along with a Justification, but with or without a definite financial estimate. These letters are scrutinized by the Presidert of Curative Medicine. He selects some Items and drops others. The Budget Department converts the selected ones into financial estimates in a format showing the approved budgets for the two years and the increase/decrease proposed for the budget year under each accounting classification.

These financlal needs are passed on to the Budget Committee, appointed by the Minister of Public Health each year. The committee currently at work on 1357. budgets consists of the Deputy Minister (who is the chairman of the comittee), the Presidents of General Health, Administration, Planning, Preventive and Curative Departments, General Director of Basic Health Services, Deputy President of Administration, General Director and Director of the Budget Department in the Presidency of Administration. The Committee is internal to the Ministry of Public Health and has no representatives from the Ministry of Finance.

The Budget Committee met almost every day for a month. The consideration of each item of the various requests, and the fustifications rrovided by the Provincial Health officers took about a week. The knowledge and experience of the members is a critical factor in the acceptance of the need for inclusion in the budget. The members gain personel knowledge of the provincial problems when they visit some of the hospitals as part of official or personal trips.

The Director of the Budget Department explained the deliberations:

We know most of the hospitals need maintenance. In 1356 we budgeted 5 mill1 on Afghanis under head Bob 250 for maintenance for the whole ministry. For 1357 it will probably be around 4 million. Sometimes we provide money even where a Provincial liealth officer has not requested any specifically. 
Exhibit 5

(continued)

page 2

Kataghan Hospital

\section{A Brief Note on the Budgeting Process}

For example, the President of Administration visited the Kandahar Hospital recently. He found that the hospital needed repairs. Although no request was there, we provided some budget for the item.

The Minister makes an aggregated request to the Ministry of Finance. The Ministry of Finance then indicates the total amount available to the Ministry of Public Health. In 1356, the amount sanctioned to the Health Ministry was 315 million Afghanis (13.7\% up over 1355) against 428 million requested. For 1357 the request was expected to be around 404 million but the amount likely to be provided was estimated at 362 million.

After the exact amount is known, the Minister of Public Health meets with all the heads of departments and sub-departments. He gives a background of the financial situation and some guidelines on where to cut the budget expenditure. The big items of expansion are discussed individually to prune the list. Discussions are held with the Presidents of the major hospitals and projects.

The Director of the Budget Department explained:

The heads of departments then prepare the budgets for individual units. In the case of hospitals, The President of Curative Medicine will work on the percentage increase provided to the ministry. Although the general increase may be 15 per cent, he can give more or less to a provincial hospital or central institute depending on his judgement about the situation.

Based on these indications, the Budget Department determines the detailed budgets by Bob, Fasel and Moda for each of about 250 spending units. Examples of the spending units are: a provincial hospital, a basic health center, a department of the Public Health Institute. These approved budgets (Form B2O) are sent to each unit, Woleswalis (district governors), Provincial Governor, Mustufiat in each province, Ministry of Finance, Accounting Department, etc. The Accounting Department sends similar data in another format breaking the annual budget down into four equal parts, one for each quarter.

The Budget Department does not receive any reports on actuals during the year. The Mustufiats in each province send the actual expenditures aggregated by all the spending units in the province to the Accounting Department in the Presidency of Administration of the Ministry of Public Health. The Budget Department had set up a section in 1976-77 to receive 


\section{Exhibit 5 \\ (continued) \\ page 3 \\ Kataghan Hospital \\ A Brief Note on the Budgeting Process}

actual expenditure statements from six large spending units in Kabul such as the Jamhuriat Hospital and the Central Workshops.

When a Provincial Health Officer made an urgent request for emergency additional funds under any particular head, the Minister or Deputy Minister made the final decision. If approved, the Accounting Department filled Form M39 and sent it to the Mustufiat so that he could allow that additional expenditure subject to the usual control procedures. 
Exhibit 6

Kataghan Hospital

Kataghan Provincial Budget Requests for 1357 (1977-78)

August 27, 1977

$(5-9-1356)$

3027

Kataghan Province

Public Health Office

Administrative office

To the Department of Curative Medicine:

According to your instructions here is the original organizational chart and budget for 1356 and the anticipated organizational chart and budget for 1357 of the Public Health Office of Kataghan Province. On these charts which are provided into two pages the inconveniences such as lack of personnel and allocation of budget for this year is written down.

Along with the copy of this letter we are sending the copies of the document to the Bepartment of Administration and expect that they should consider our problems regarding personnel and budget for 1357. We have been having difficulties getting personnel, employees and contract employees. Furthermore, there are many employees who haven't gotten their promotion yet. These are main concerns that should be considered as soon as possible.

We should add that the organization and budget for 1357 of the Basic Health Centers will be, indeed, considered by the concerned department.

Sincerely,

Dr. Hasan Ali Mahmud

PHO - Kataghan Province

cc: Department of Administration

Minister's Secretariat office 
Exhibit 6

(continued) page 2

Kataghan Hospital

Kataghan Provincial Budget Requests for 1357 (1977-78)

Anticipated Organization of Kataghan Public Health Office for 1357:

A. In 1356 the rank for the person to be in-charge of Kataghan Public Health Office was determined 3. Now that the Kataghan Public Health Office is not only handling affairs of Gandhara PHO but also the Basic Health Centexs, it is necessary that the administrative as well as technical personnel of the Kataghan PHO should be expanded. Therefore, the organization and budget of Kataghan. Public Health office for 1357 would be presented as follows:

1. Ranis 2 instead of rank 3 for the position of PHO should be determined since the rank of X-ray doctor is 5 and the position is 5 too, our suggestion is to determine position 4 in 1357 in order to encourage the $\mathrm{X}$-ray doctor.

2. A new nurse having rank 6 is needed for 1357 to the nursing of fice to do registration and medical recording.

3. Approval of a new position for an executive clerk to do affairs related to personnel, $\mathrm{PHO}$, etc.

4. Besides the organization of 1356 approval of a new position for 1357 for a clerk having rank 9 to take care of the former files häven't been processed yet.

5. A person to be in-charge of cash and take care of the income of the hospital plus other incomes. Instead of position 7, position 6 should be approved for 1357 .

6. The position of the cook should be promoted from 9 to 7 .

7. In 1357 a new position should be opened (position 10 as a contractor) for assistant to the cook.

8. Position 9 instead of 10 for the tailor and launderer.

9. In 1357 position 6 instead of 7 for the typist to accomplish effective jobs.

10. The vehicle (jeep) available at PHO is not doing only affairs of the PHO and hospital but also the health center. Hence, the position of driver should be promoted from 7 to 6 . 


\author{
Exhibit 6 \\ (continued) \\ page 3 \\ Kataghan Hospital \\ Kataghan Provincial Budget Requests for 1357 (1977-78)
}

11. In order to keep clean the rooms of the patients and services of internal, surgery, polyclinic, female, etc., besides the organization of 1356 five new contractors with scale 11 is needed.

12. The duty of the gate guards during the day and night is very important. Positions 9 should be approved instead of 11 .

13. Besides organization of 1356 two new positions (rank Il) should be approved for 1357 .

14. Position 10 instead of 11 for the barber.

15. One manager with rank 8 to take care of the equipment and the office of the PHO itself.

16. One peon for the archives (scale 11) should be determined.

17. Extra or surplus expenditures for education and food allowance should be anticipated at 200,000 Afs.

B. Because of the allocation of the budget which was not completely approved for 1356 there was lots of inconveniences. Besides allocation of 1356 the new anticipated budget for 1357 will be suggested as follows:

18. According to Fasel 210 in 1356 the allocated budget for telephone calls and communication was 18,000 Afs and was approved. This budget should be increased for the same purpose 30,000 Afs.

19. According to Fasel 220 the amount of 4,000 Afs was approved in 1356 for advertisements. This money was not enough. Either we made the ministry to advertise for us or we avoided advertising our ads. This amount should be increased to 15,000 Afs in 1357.

20. In 1356 purchases of office supplies (stationery) was allowed to be done with 22,000 Afs. In 1357 this amount should be increased to 40,000 Afs.

21. Lack of enough space to use as warehouses. Right now plenty of valuable supplies are located in the open air. The falling of the snow and rain will damage these supplies. Also most of the important personnel don't have office space. Hope they consider the issue and allocate budget so that this problem is solved.

22. The water system of the hospital is not good. Also, the building of the hospital needs to be remodeled. Special attention should be paid. 


\section{Exhibit 7}

Kataghan Hospital

1357 Budget Requests from Hospital and Action at MOPH

\section{Request}

A. 1. Up PHO Rank 3 to 2

Up X-ray doctor Rank 5 to 4

2. New nurse Rank 6

3. New Personnel Clerk

4. New Filing Clerk in Rank 9

5. Up Cash Clerk from Rank 7 to 6

6. Upgrade Cook's Rank 9 to 7

7. New Asst. Cook (Contractor)Rank 10

8. Upgrade Tailor \& Launderer Rank 10 to 9

9. Up Typist Rank 7 to 6

10. Up Jeep Driver's Rank 7 to 6

11. Five New Contractors Scale 11

12. Up Guard's position from Rank 11 to 9

13. Two new positions Rank 11

14. Up Barber's position from Rank 10 to 11

15. New Manager Rank 8

16. New Peon Rank 11

17. Extra for Education \& Food Allowance up from 176,000 to 200,000
Action

Not Possible Now

Give Head Nurse Rank $5+33,000$

Given in Rank 8

Given

Granted

Not Granted

Not Granted

Not Granted

Granted

Not Granted

Granted

Two guards now in Rank 11

Upgrade both to Rank $10+2,160$

Granted

Not Granted

Not Granted

Granted

Budgeted 194,000

B. 18. Up Telephone Budget from 18,000 to 30,000 Afs

19. Up Advtg. Budget Irom 4,000 to 11,000 Afs

20. Up Stationery Budget from 22,000 to 40,000 Afs.

21. Allocate Budget for Warehouse Space

22. Pay Special Attention to Water System

Budgeted 25,000 Afs $\quad+7,000$

Budgeted 5,000 Afs $\quad+1,000$

Budgeted 25,000 Afs $\quad+3,000$

None

None

$+22,560$

$+3, \overline{600}$

$+56,400$

Financial Effect

$+22,800$

$+3,600$

$+11, \overline{280}$

$+18,000$ 
Exhibit 7

(continued)

page 2

Kataghan Hospital

1357 Budget Requests from Hospital and Action at MOPH

1. Not Asked But Given One Doctor of Rank 5

2. Not Asked But Promoted Two Doctors from Rank 6 to Rank 5

$+33,000$

3. Not Asked But Promoted One Sanitarian Rank 8 to Rank 6

4. Not Asked But Promoted One Compounder Rank 8 to Rank 7

5. Not Asked But Promoted One Storekeeper Rank 7 to Rank 6

$+6,000$

$+7,200$

$+3,600$

$+3,600$

6. Not Asked But Promoted One Mechanic Rank 9 to Rank 8

$+1,800$

7. Not Asked But Promoted One Admin. Director Rank 5 to Rank 4

$+3,600$ 
Exhibit 8

Katạghan Hospital

Budgeted and Actual Expenditures of Kataghan Province

(Hospitals and Basic Health Centers)

(In thousands of Afghanis)

\begin{tabular}{|c|c|c|c|c|c|c|c|}
\hline $\begin{array}{l}\text { Budget } \\
\text { Item }\end{array}$ & \multicolumn{2}{|c|}{1354} & \multicolumn{2}{|c|}{1355} & \multicolumn{2}{|c|}{1356} & $\begin{array}{l}1357 \\
\text { Estimated } \\
\text { Budget }\end{array}$ \\
\hline 100 Personal Services & 3,838 & 3,225 & 5,232 & 4,318 & 5,305 & 3,295 & 5,856 \\
\hline $\begin{array}{l}110 \text { Base Pay } \\
130 \text { Additional } \\
140 \text { Cash Remuneration }\end{array}$ & $\begin{array}{r}3,447 \\
311 \\
60\end{array}$ & $\begin{array}{r}2,776 \\
444 \\
5\end{array}$ & $\begin{array}{r}4,536 \\
636 \\
60\end{array}$ & $\begin{array}{r}3,831 \\
483 \\
4\end{array}$ & $\begin{array}{r}4,605 \\
640 \\
60\end{array}$ & $\begin{array}{r}2,916 \\
365 \\
14\end{array}$ & $\begin{array}{r}5,093 \\
683 \\
80\end{array}$ \\
\hline 200 Other Services & 245 & 135 & 286 & 152 & 409 & 59 & 380 \\
\hline $\begin{array}{l}210 \text { Communications } \\
220 \text { Prtg. Advtg. } \\
230 \text { Utility } \\
240 \text { Rent } \\
250 \text { Maintenance } \\
260 \text { Travel } \\
270 \text { Freight } \\
280 \text { Others }\end{array}$ & $\begin{array}{l}37 \\
19 \\
65 \\
31 \\
37 \\
32 \\
14 \\
10\end{array}$ & $\begin{array}{r}27 \\
8 \\
42 \\
25 \\
7 \\
25 \\
-\quad 1\end{array}$ & $\begin{array}{l}43 \\
19 \\
87 \\
22 \\
52 \\
35 \\
18 \\
10\end{array}$ & $\begin{array}{r}25 \\
2 \\
40 \\
25 \\
35 \\
21 \\
3 \\
1\end{array}$ & $\begin{array}{r}56 \\
20 \\
98 \\
21 \\
115 \\
64 \\
18 \\
17\end{array}$ & $\begin{array}{r}8 \\
1 \\
23 \\
5 \\
2 \\
17 \\
1 \\
2\end{array}$ & $\begin{array}{l}63 \\
21 \\
96 \\
21 \\
79 \\
68 \\
16 \\
16\end{array}$ \\
\hline 300 Materiels, Supplies & 810 & 671 & 962 & 515 & 1,062 & 275 & 1,002 \\
\hline $\begin{array}{l}310 \text { General } \\
320 \text { Transportation } \\
330 \text { Agricultural } \\
340 \text { Construction } \\
350 \text { Office } \\
360 \text { Scientific } \\
370 \text { Comm. \& Power }\end{array}$ & $\begin{array}{r}684 \\
40 \\
2 \\
24 \\
39 \\
5 \\
16\end{array}$ & $\begin{array}{r}617 \\
-\quad 3 \\
-3 \\
41 \\
-\quad 1\end{array}$ & $\begin{array}{r}799 \\
42 \\
2 \\
37 \\
54 \\
10 \\
18\end{array}$ & $\begin{array}{r}475 \\
2 \\
-\quad 18 \\
19 \\
-\quad 1\end{array}$ & $\begin{array}{r}868 \\
69 \\
3 \\
38 \\
62 \\
6 \\
16\end{array}$ & $\begin{array}{r}221 \\
11 \\
- \\
14 \\
29 \\
- \\
-\end{array}$ & $\begin{array}{r}807 \\
68 \\
4 \\
38 \\
65 \\
6 \\
14\end{array}$ \\
\hline 400 Equipment & - & 11 & 50 & 23 & 15 & 4 & 12 \\
\hline TOTAL & 4,893 & 4,042 & 6,530 & 5,008 & 6,791 & 3,633 & 7,350 \\
\hline
\end{tabular}


Exhibit 9

Kataghah Hospital

Sanctioned Budgets and Actuals of the Kataghan Hospital - 1354-1357

(In thousands of Afghanis)

\begin{tabular}{|c|c|c|c|c|c|c|}
\hline $\begin{array}{l}\text { Deseription } \\
\text { Bob }\end{array}$ & $\begin{array}{r}1973- \\
\text { Sanctioned } \\
\text { Budget }\end{array}$ & $\begin{array}{l}-74 \\
54 \\
\text { Actuals }\end{array}$ & \begin{tabular}{|c|}
$1974-75$ \\
1355 \\
Sanctioned \\
Budget
\end{tabular} & $\begin{array}{r}1975 \\
13 \\
\text { Sanctioned } \\
\text { Budget }\end{array}$ & \begin{tabular}{|l|}
-76 \\
56 \\
Actual \\
first \\
$(9 \mathrm{mo})$. \\
\end{tabular} & $\begin{array}{l}1976-77 \\
1357 \\
\text { Estimate }\end{array}$ \\
\hline $\begin{array}{l}110 \text { Civilian Base Pay } \\
130 \text { Additional } \\
140 \text { Cash Remuneration }\end{array}$ & $\begin{array}{r}988 \\
98 \\
40\end{array}$ & & $\begin{array}{r}1,265 \\
185 \\
40\end{array}$ & $\begin{array}{r}1,233 \\
17.6 \\
40\end{array}$ & $\begin{array}{r}860 \\
93 \\
14\end{array}$ & $\begin{array}{r}1,403 \\
194 \\
60\end{array}$ \\
\hline 100 Personal Services & 1,126 & & 1,490 & 1,449 & 967 & 1,657 \\
\hline $\begin{array}{l}210 \text { Communications } \\
220 \text { Printing \& Advtg. } \\
230 \text { Utility } \\
250 \text { Maintenance } \\
260 \text { Travel } \\
270 \text { Freight } \\
280 \text { Others }\end{array}$ & $\begin{array}{r}8 \\
4 \\
28 \\
16 \\
5 \\
4 \\
1\end{array}$ & & $\begin{array}{r}15 \\
4 \\
40 \\
24 \\
5 \\
8 \\
1\end{array}$ & $\begin{array}{r}18 \\
4 \\
42 \\
86 \\
12 \\
6 \\
6\end{array}$ & $\begin{array}{r}8 \\
-\quad 20 \\
-\quad 2 \\
-\quad 2\end{array}$ & $\begin{array}{r}25 \\
5 \\
40 \\
50 \\
16 \\
4 \\
5\end{array}$ \\
\hline 200 Other Services & 66 & & 97 & 174 & 32 & 145 \\
\hline $\begin{array}{l}310 \text { General Mtrls. } \\
320 \text { Transport. Mtrls. } \\
330 \text { Agr. Mtrls. } \\
340 \text { Construc. Mtrls. } \\
350 \text { Office } \\
360 \text { Scientific } \\
370 \text { Comm.\&Power }\end{array}$ & $\begin{array}{r}332 \\
5 \\
1 \\
5 \\
15 \\
4 \\
4\end{array}$ & & $\begin{array}{r}437 \\
7 \\
1 \\
10 \\
22 \\
8 \\
7\end{array}$ & $\begin{array}{r}406 \\
7 \\
2 \\
8 \\
22 \\
4 \\
5\end{array}$ & $\begin{array}{r}2 \\
12\end{array}$ & $\begin{array}{r}345 \\
6 \\
3 \\
8 \\
25 \\
4 \\
3\end{array}$ \\
\hline $300 \frac{\text { Materials, Supplies }}{\text { and Farts }}$ & 366 & & 492 & 454 & 86 & 394 \\
\hline 490 Furnishings & - & & 50 & 15 & 4 & 12 \\
\hline 400 Equipment & - & & 50 & 15 & 4 & 12 \\
\hline $\mathrm{T} O \mathrm{TAI}$ & 1,558 & $* 1,532$ & 2,129 & 2,092 & 1,089 & 2,208 \\
\hline
\end{tabular}

*From a different source than other data 


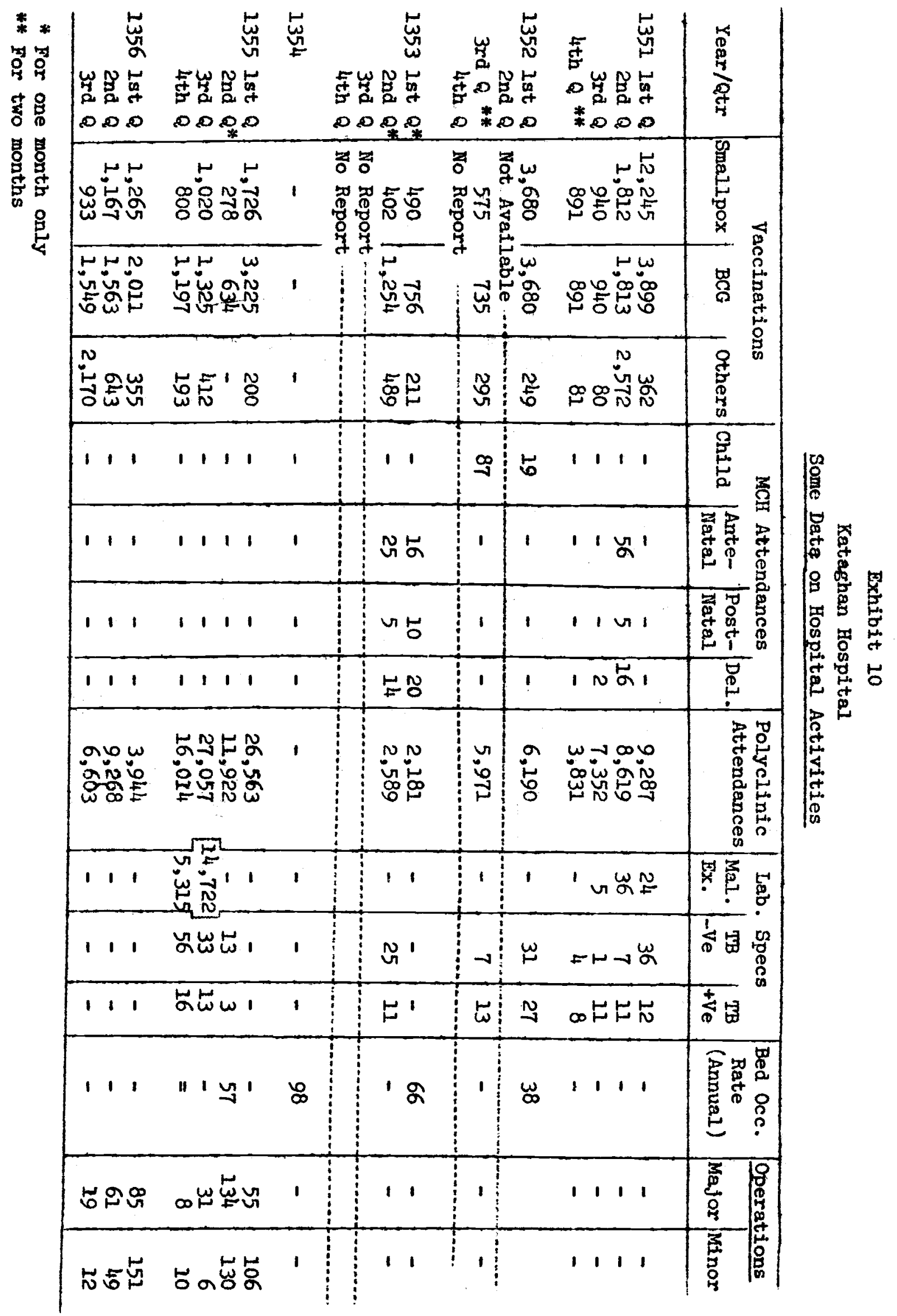


Exhibit 11

Kataghan Hospital

Some Data on Basic Health Centres in the Province

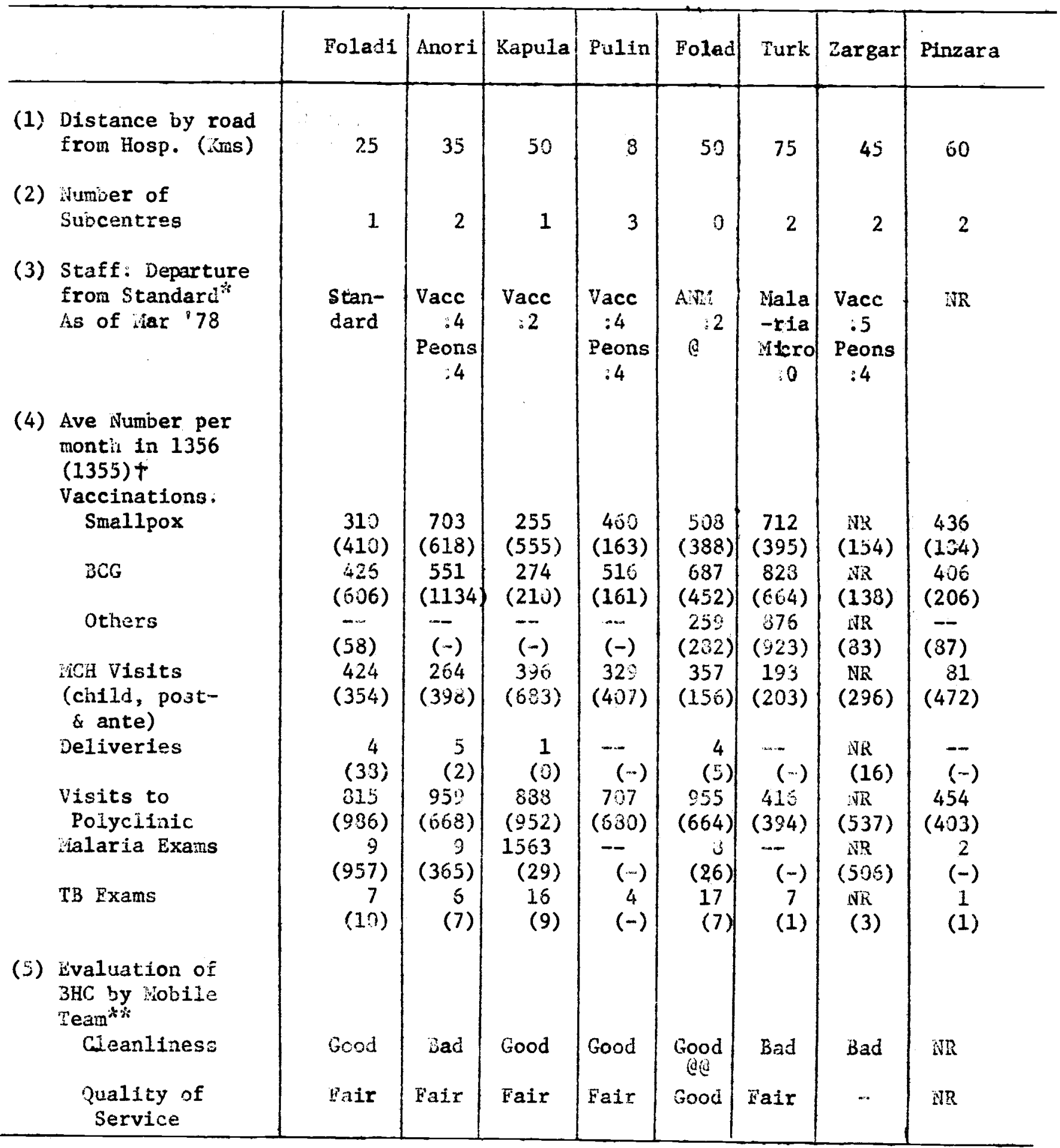


Exhlbit 11

Kataghan Hospital

Some Data on Basic liealtin Centres in the Province

(cont'd.)

*Standard BHC Staff: Doctor, Nurse, ANM, Sanitarian, Vaccinators(3), Lab Technician, Malaria Milcroscopist, Storekeeper, Clerk, Driver, Peons (3). Figures skown in columng are actuals where there were departures from standard.

A As of August '77; As of March '78 the staff at the BHC consisted of only.one doctor and one sanitarian.

† 1356 (i.e. 1976-77) is based on data for first two quarters. Figures in brackets are for 1355 (i.e., 1975-76).

iNR: Wo Report

** Most evaluations are as of March "73 (End of 1356)

ad As of August"'77; March '78 evaluation: Bad. 
Management Sciences for Health

Kabul

Miran Hospital (A)

'I want to send you somewhere. Please don't say no.' That was what the Minister of Public Health told Dr. M. Viyazi when he was posted as Provincial Health Officer of Miran on October 26, 1977.

In his sixteen years with the Ministry of Public Health, Dr. Niyazi had served in different capacities, programs and areas -- Malaria Institute In Kabul, Bakhtar, Hariwa and various other places, in Basic Health Centers in the field, and in the Ministry at Kabul as an administrator of health services. Over the years, he had moved up to rank 4. Immediately before becoming the Provincial Health Officer of Miran, Dr. Niyazi was the head of the Masood Training Institute. There he occupled a position of rank 4. The new Provincial Health officer's position was of rank 3 . It was an opportunity for advancement. Dr. Niyazi was also aware that Miran was a risky proposttion. It had a history of problems and poor performance. The Minister and senior Ministry officlals were keen on seeing some improvement in health services in Miran.

Several earlier Provincial Health Officers of Miran had moved out without achieving a record of success there. The situation, therefore, was full of challenge and opportunity for Dr. Niyazi. He was wondering how he should proceed in his new job.

Cholce of Dr. Niyazi

Dr. Abdul Hakim, President of Curative Medicine, explained the circumstances under which the choice was made:

The general transfers for all categories . doctors and others ... used to be made every two years. Recently we increased the duration to three years. For medical officers, the transfer committee is often chaired by the Minister. Otherwise, the Deputy Minister is in the chair, with presidents of

Case material of Management Sclences for Health prepared by Dr. $K$. R. Srinivasa Murthy. A case is not designed to illustrate either correct or inccrirect handling of administrative probleins. $7 / 78$ 
various departments as members. We try to give each a mix of good and bad places. In addition, we take the local situation into consideration while transferring provinclal health officers and basic health center doctors. For provinclal health officers we look for good experience in areas of specialization, knowledge of public health and administrative skills.

Dr. Hiyazi was the fourth Provinclal Health Officer of Miran in five years. The earlier officers had served for varying periods as follows:

$\begin{array}{llll} & \text { From } & \text { To } & \text { Years-Months } \\ \text { Dr. Mohamad Yusuf } & 3 / 73 & 3 / 74 & 1-1 \\ \text { Dr. Abdul Hussein } & 3 / 74 & 11 / 75 & 1-8 \\ \text { Dr. Ahmedullah } & 11 / 75 & 10 / 77 & 2-0\end{array}$

Dr. Hakim explained the procedure for special cases:

In addition to normal transfers, we have meetings to deal with special transfer cases because of extenuating circunstances. In such cases, we do not consider the duration of the person's stay at a place. Special cases would be where the Provincial Health Officer is having trouble or when we get complaints from employees, patients, or the Provincial Governor.

The transfer of Dr. Niyazi to Miran was not a routine one. Miran was not working well. We had several complaints. The PHO was having frequent clashes with his staff. The administration was not good.

Miran had a long history of problems. As early as January 1974 , the Ministry appeared to have been disappointed with the administration of the hospital. Excerpts from a report by Dr. Asgar Ali, Chief of the Tuberculosis Institute, Kabul, are given in Exhibit 1. The Minister had requested him to report on Miran.

Dr. Hakim explained:

Several of us, including the Minister, visited Miran three times last year. Our inspection department and the President of Nursing also visited the place. The reports of the visiting teams confirmed the general complaints.

In Dr. Niyazi, we found a good record in public health and some training and experfence in administration. We decided to transfer him to Miran. 
The Provincial Health officer

The Provincial Health Officer was the senior-most official of the Ministry of Public Health in the Province. He functioned technically under the Curative Medicine Department of the Ministry (Exhibit 2). However, many other Presidencles and Central Inst1tutes supported the Provincial Health officer and evaluated the services. The Presidency of Administration dealt with the budgets, in conjunction with the Curative Department. The Preventive Medicine Presidency, through the General Director of Basic Health Services, tealt with the Basic Health Centers, in providing them with staff and resources. However, the PHO was expected to supervise the functioning of the Basic Health Centers. The Preventive Medicine Department supported the preventive immunization work done at the Provincial Hospital, in addition to those at the Basic Health Centers.

As the senior-most official of the Ministry of Public Health in the Province, the PHO was expected to advise and assist the Provincial Governor, a high-ranking official of the Ministry of Interfor. PiiOs often attended the meetings of senior officials of other ministries called by the Provincial Governor. The Provincial Governor evaluated the work of the PHO in administrative and other terms in addition to the evaluation done by the Curative Department in the Ministry of Public Health. The Provincial Governor was the authorizing/approving officer for purchases for the hospital. He appointed the purchase committees required under the regulations governing purchase of cormodities by State Departments.

The various roles and relationships expected of the Provincial Health officer are shown in a chart in Exhib1t 3 . Excerpts from a job description, accepted by the Ministry of Public Health are given in Exhibit 4.

\section{Miran Province}

Miran was one of the largest provinces and had a population of about 1 million. Yet, medical services in Miran were very scarce. It had only 2 hospitals which together had just 40 beds. There were 8 Basic Health Centers with 3 sub-centers. Altogether there were 34 pharnacies, of which one was a government pharmacy. Malnutrition among children was one of the highest in Miran. The student population was estimated at about 40,000 in $1355,25,000$ of whom were in 84 primary schools.

\section{Miran Provinclal Health Office}

There were 8 doctors, including the Provinclal Health officer, and 3 nurses in Miran. A list of personnel attached to the Miran Provincial Hospital is given in Exhibit 5. There were 48 employees in all, with an additional nine vacancies. 
The sanctioned and actual budgets for the Miran Hospital are given in Exhibit 6. In 1355, the hospital utilized 1.892 million Afghanis out of its budget of 2.070 million, a utilization rate of 91 percent. : In 1354, the utilization rate was less than 70 percent. The financial data for Miran Province, covering both hospitals and the basic health centers, are given in Exhibit 7. Some data on the hospital activities are provided in Exhibit 3. Available data on the basic health center activities are given in Exhibit 9. The basic health centers were widely scattered and the roads were rough. The elght centers could be covered with about two hours at each center in two trips, each of two days, with an overnight halt at one of the centers. 
EXHIBIT 1

Hiran Hospital (A)

Excerpts from a Report by Dr. Asgar All,

Chief of the Tuberculosis Institute, on

Miran Hospital as of January 1974

- The attftude of tire PHO was not good.

-. The surroundings of the hospital were not clean. Grounds and garden had received no attention. The approach to the hospital was a dirt road. The PHO had made no attempt to level 1 t with sand and gravel. PHO claimed that the road should be paved with concrete.

- Discipline was lacking in the hospital. The PHO's office was on the first floor and he was surrounded by patients and some doctors without work. Visitors were all around and freely entered any room.

- All the beds were dirty. The rooms needed repair.

- Ten of the 30 beds were occupied - seven with internal medicine patients and three with surgery patients. Of the six doctors, including a dentist, three were surgeons. Miran does not need three surgeons. The doctors admitted they were not doing anything.

- The dentist was working under sunlight and had no other equipment or lighting.

- The X-ray section was housed in a new building, but the equipment was not proper and could only be used for small orthopedic cases. The dark room was unhygienic.

- Both the kerosene refrigerator and the autoclave were out of order. 
Exhlbit 3

Miran Hospital (A)

\section{A Chart Showing Some Relationships of the PHO}

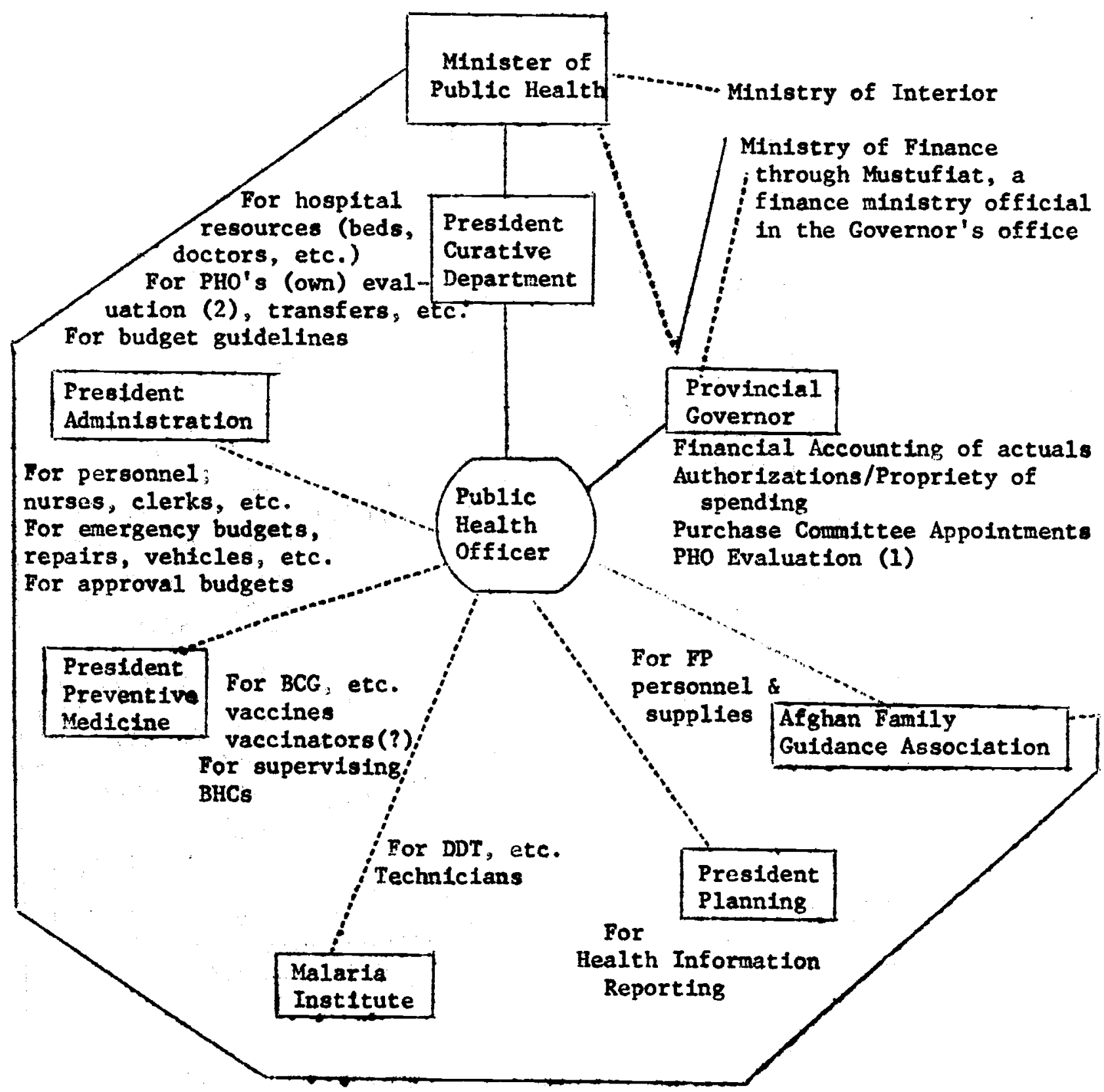




\section{Exhibit 4 \\ Miran Hospital (A)}

Excerpts from the Job Description of the Provinclal Health Officer

Scope: His activity is not limited to curative medicine. Most of his responsibilities and activities are in the area of preventive medicine.

Objectives: Implement the technical objectives of the Ministry of Public Health. Reach physical, mental and environmental health services to the majority of the people in the province. Will advise the Provincial Governor on health and be responsible to him.

Relationships: Will enlist the cooperation of other representatives in the implementation of health programs. Provide, on request, services to the military, police and other forces. Supervise.the health services provided by other institutions in the province.

JOB

Information Gathering: Gather up-to-date information on: (1) geography, (ii) social and cultural characteristics, (iii) economics, and (Iv) contaglous arid non-contaglous diseases of the permanent and the floating population.

Information Dissemination: (i) Enlighten, educate and Involve the people in health consistent with peoples' bellefs and the Ministry's program objectives, (i1) Hold seminars, courses and workshops for his staff and find solutions to problems within his authority.

Budget Ing: Administer the funds allocated according to the budget rules and regulations.

Reporting: (1) Send on time monthly, quarterly, and annual reports, prepared scientifically to the relevant Government departments, (1i) In addition to taking action on contagious diseases, he should immediately report on it to the concerned office in the fastest possible way, (iii) report every year on the cash and property to the concerned presidency, (iv) report on unwanted drugs, equipment, supplies, etc., at the hospitals and in the health centers, ( $v$ ) report quarterly the expenditure of the public health office and the health centers to the Ministry ${ }^{\circ} s$ budget department.

Supervision: (1) Basic Health Centers - visit at least once in three months, (11) Personnel .. that they are present and do their duty, send legitimate requests for transfer and extension (Form P2 filled in by employee) to the concerned presidencies in the Ministry if they are reasonable. 
(continued)

Excerpts from the Job Description of the Provincial Health Officer

Operations: (1) proper storage and use of drugs, supplies, equipment, foodstuffs, etc., (ii) record and protect the property of the government at the hospitals and health centers, (1ii) plant trees in the surrounding areas, (iv) maintain and ensure legitimate use of vehicles, buildings, and equipment, (v) control the prices of drugs sold by private pharmacies, (vi) prevent unnecessary expenditure, (vii) collect the monies due to the government, (vili) transfer the income to the Ministry of Finance bank accounts in ten days, (ix) generate income for the return trips of vehicles that bring medicines and supplies from Kabul to the hospital and health centers, $(x)$ return the serum bottles, containers, etc., if no other cargo incone can be generated and, in any case, not retain the vehicle for more than three days, ( $x i)$ settle the per diem and bus fares of staff from the alloted fund (can request the creation of such a fund if one does not exist), (xii) make a trustee responsible for cash and property. 
Exhlbit 5

Miran Hospital (A)

\title{
Technical and Administrative Personnel As of End 1356
}

\author{
Position No. $\underline{\text { Rank }}^{\circledR} \quad \underline{\text { Person }}$
}

Employees:

$\begin{array}{llll}\text { Provincial Health officer } & 1 & 4-3 & \text { Dr. M. Niyazi } \\ \text { Assistant PHO } & 1 & 7-5 & \text { Dr. M. Rafi } \\ \text { Doctors } & 5 & 4,5,6,6, \& 7 \\ \text { Adninistrative Director } & 1 & 4 / 5-6 & \text { Mr. Ananullah } \\ \text { Property Clerk } & 2 & 7 \& 10-9 & \\ \text { Administrative Clerk } & 2 & 8 \& 10-9 & \\ \text { Sanitarian } & 1 & 6 / 7-7 & \text { Jamaluddin } \\ \text { X-ray Technician } & 1 & 8-6 & \text { Ifzali } \\ \text { Lab Technician } & 1 & 9-8 & \text { Ashrafi } \\ \text { Head Nurse } & 1 & 10 & \text { Siddique } \\ \text { Hurses (female) } & 2 & 7 \& 9 & \text { Rahima \& Zarghuna } \\ \text { Pharmacist } & 1 & 9 & \text { Rahman } \\ \text { Vaccinators } & 4 & 9,10,10 \& 11-10 \\ \text { Mechanic } & 1 & 9 & \text { Rahimatullah }\end{array}$

Sub-total 24

\section{Contract Employees:}

$\begin{array}{lcl}\text { Storekeeper } & 1 & 6 \\ \text { Pump Mechanic } & 1 & 7 \\ \text { Driver } & 1 & 7 \\ \text { Assistant Storekeeper } & 1 & 9 \\ \text { Others * } & 20 & 11\end{array}$

Sub-total 24

TOTAL 48

Vacancies: 1 Doctor (rank 8), 4 nurses (two of rank 7 and one each of ranks 6 and 8 ), two nurse midwives (rank 9), 1 compounder (rank 8), and 1 medical recorder (rank 9).

* 10 peons, 2 untrained nurses, 2 guards, 1 barber, 1 launderer, 1 gardener, 1 cook, and 1 assistant cook

(a) An entry 4-3 means: the rank of the civil servant is 4. He is occupying a position which has rank 3. The civil servant normally gets one-third of the difference in salary between rank 4 and 3 for each year he performs the duties of the position of rank 3. In three years, therefore, he would get the full salary of rank 3, unless he is pronoted to rank 3 earlier. 
Exhibit 6

Miran Hospital (A)

Sanctioned Budgets and Actuals for Miran Hospltal: 1354 - 1357

\begin{tabular}{|c|c|c|c|c|c|c|c|}
\hline \multirow{2}{*}{$\begin{array}{l}\text { Description } \\
\text { Bob/Fasel }\end{array}$} & \multirow{2}{*}{\multicolumn{2}{|c|}{\begin{tabular}{c|c|}
1354 \\
Budget & Actual
\end{tabular}}} & \multicolumn{2}{|c|}{1355} & \multicolumn{2}{|c|}{1356} & \multirow{2}{*}{$\begin{array}{c}1357 \\
\text { Estimate }\end{array}$} \\
\hline & & & Budget & Actual & Budget & $\begin{array}{l}\text { Actual } \\
(9 \text { mo })\end{array}$ & \\
\hline $\begin{array}{l}110 \text { Civilian Base Pay } \\
130 \text { Additional } \\
140 \text { Cash Remuneration }\end{array}$ & $\begin{array}{r}946 \\
88 \\
60 \\
\end{array}$ & $\begin{array}{r}812 \\
27 \\
22 \\
\end{array}$ & $\begin{array}{r}1200 \\
172 \\
0 \\
\end{array}$ & $\begin{array}{r}1145 \\
136 \\
30 \\
\end{array}$ & $\begin{array}{r}1175 \\
168 \\
60 \\
\end{array}$ & $\begin{array}{r}799 \\
160 \\
52 \\
\end{array}$ & $\begin{array}{r}1395 \\
189 \\
\quad 60 \\
\end{array}$ \\
\hline 100 Personal Services & 1094 & 861 & 1432 & 1311 & 1403 & 1011 & 1644 \\
\hline 210 Communications & 15 & 7 & 15 & 7 & 20 & - & $\begin{array}{r}25 \\
5\end{array}$ \\
\hline $\begin{array}{l}220 \text { Printing \& Advtg. } \\
230 \text { Utility }\end{array}$ & 5 & 1 & 5 & $\ldots$ & 5 & 5 & 5 \\
\hline 240 Rent & $\begin{array}{r}35 \\
5\end{array}$ & $\begin{array}{r}12 \\
1\end{array}$ & $\begin{array}{r}35 \\
5\end{array}$ & 25 & 40 & $\begin{array}{r}34 \\
2\end{array}$ & _. \\
\hline 250 Maintenance & 25 & 8 & 25 & 15 & 20 & 16 & 50 \\
\hline 260 Trave1 & 18 & 6 & 18 & 15 & 16 & 7 & 16 \\
\hline $\begin{array}{l}270 \text { Freight } \\
280 \text { Others }\end{array}$ & $\begin{array}{l}8 \\
2\end{array}$ & 3 & $\begin{array}{l}8 \\
2\end{array}$ & - & $\begin{array}{l}4 \\
5\end{array}$ & $\begin{array}{l}1 \\
0\end{array}$ & $\begin{array}{l}4 \\
5\end{array}$ \\
\hline 200 Cther Services & 113 & 38 & 113 & 62 & 110 & 65 & 145 \\
\hline 310 General Materials & 304 & 146 & 445 & 445 & 405 & 384 & 345 \\
\hline 320 Transportation ittr1s. & 8 & - & 8 & 8 & 6 & & 6 \\
\hline 330 Agr. Materials & 1 & - & 1 & 1 & 3 & & 3 \\
\hline 340 Construct1on Mtrls. & 11 & $-\infty$ & 17 & 14 & 8 & 4 & 8 \\
\hline 350 Office Materials & 17 & 9 & 19 & 18 & 25 & 17 & 25 \\
\hline 360 Scientific Materials & 4 & -- & 8 & 7 & 4 & 1 & 4 \\
\hline 370 Corm. \& Power Mtrls. & 5 & $=$ & 5 & 4 & 3 & 3 & 3 \\
\hline 300 Mater1a1s, Supplies & 350 & 155 & 503 & 497 & 454 & 409 & 394 \\
\hline 490 Furnishings & 15 & $=$ & 22 & 22 & 12 & 12 & 12 \\
\hline 400 Equipment & 15 & $\approx$ & 22 & 22 & 12 & 12 & 12 \\
\hline & 1572 & 1054 & 2070 & 1892 & 1979 & 1497 & 2195 \\
\hline
\end{tabular}


Exhibit 7

Miran Hospital (A)

Approved Budgets and Actual Expenditure for Miran Province

(In thousands of Afghanis)

\begin{tabular}{|c|c|c|c|c|c|c|c|}
\hline Budget Item & Budget & 354 & Budget & $\begin{array}{l}355 \\
\text { Actual }\end{array}$ & Budget & $\begin{array}{l}356 \\
\text { Actual } \\
(10 \mathrm{mo})\end{array}$ & Estimate \\
\hline 100 Personal Services & 2,842 & 2,169 & 3,977 & 2,969 & 4,085 & 2.285 & 5,402 \\
\hline $\begin{array}{l}110 \text { Base Pay } \\
130 \text { Additional } \\
140 \text { Cash Remuneration }\end{array}$ & $\begin{array}{r}2,534 \\
235 \\
73\end{array}$ & $\begin{array}{r}1,884 \\
285 \\
\ldots\end{array}$ & $\begin{array}{r}3.423 \\
481 \\
73\end{array}$ & $\begin{array}{r}2,719 \\
235 \\
15\end{array}$ & $\begin{array}{r}3,522 \\
490 \\
73\end{array}$ & $\begin{array}{r}2,024 \\
242 \\
19\end{array}$ & $\begin{array}{r}4,694 \\
628 \\
80\end{array}$ \\
\hline 200 Other Services & 276 & 356 & 285 & 129 & 328 & 122 & 426 \\
\hline 210 Communications & 40 & 23 & 40 & 22 & 53 & 5 & 64 \\
\hline 220 Printing \& Advtg. & 16 & $-\frac{1}{37}$ & 16 & 2 & 21 & 3 & 24 \\
\hline $\begin{array}{l}230 \text { Ut11ity } \\
240 \text { Rent }\end{array}$ & $\begin{array}{l}69 \\
42\end{array}$ & $\begin{array}{l}37 \\
36\end{array}$ & $\begin{array}{l}78 \\
33\end{array}$ & $\begin{array}{l}13 \\
33\end{array}$ & $\begin{array}{l}92 \\
10\end{array}$ & $\begin{array}{r}14 \\
1\end{array}$ & $\begin{array}{r}105 \\
23\end{array}$ \\
\hline 250 Maintenance & 43 & 209 & 50 & 15 & 52 & 55 & 90 \\
\hline 260 Travel & 41 & 46 & 44 & 36 & 74 & 25 & 84 \\
\hline 270 Freight & 15 & 5 & 15 & 5 & 12 & 2 & 16 \\
\hline 280 Others & 10 & $m$ & 10 & 3 & 14 & 17 & 20 \\
\hline 300 Materials, Supplles & 689 & 449 & 912 & 623 & 965 & 484 & 1,055 \\
\hline 310 General & 567 & 378 & 764 & 535 & $786^{\circ}$ & 434 & 841 \\
\hline 320 Transportation & 37 & 12 & 37 & 1 & 65. & 5 & 80 \\
\hline 330 Agricultural & 2 & 1 & 2 & $-\dot{s}$ & 4 & 1 & 4 \\
\hline 340 Construction & 26 & 4 & 39 & 39 & 34 & 6 & 43 \\
\hline 350 office & 39 & 47 & 48 & 47 & 59 & 35 & 65 \\
\hline 360 Scientific & 5 & 5 & 9 & - & 5 & 1 & 6 \\
\hline 370 Comnunication \& Power & 13 & 2. & 13 & 1 & 12 & 2 & 16 \\
\hline 400 Equipment & 15 & 17 & 22 & 14 & 12 & 12 & 12 \\
\hline TOTAL & 3,822 & 2,995 & 5,196 & 3.735 & 5,390 & 2,903 & 6,895 \\
\hline
\end{tabular}


Exhlbit 8

Miran Hospital (A)

Some Data on Hosp1tal Activities

\begin{tabular}{|c|c|c|c|c|}
\hline \multirow[t]{2}{*}{ Item } & \multirow[t]{2}{*}{1352} & \multirow[t]{2}{*}{1353} & \multicolumn{2}{|c|}{$\begin{array}{c}1356 \\
\text { Ouarters }\end{array}$} \\
\hline & & & 1 & 2 \\
\hline Vaceinations & & & & \\
\hline $\begin{array}{l}\text { BCG } \\
\text { Smallpox } \\
\text { Others }\end{array}$ & $\begin{array}{r}11,263 \\
4,749 \\
11,848\end{array}$ & $\begin{array}{r}15,307 \\
3,982 \\
2,545\end{array}$ & $\begin{array}{r}18,999 \\
14,969 \\
2,790\end{array}$ & $\begin{array}{r}11,861 \\
8,464 \\
1,511\end{array}$ \\
\hline Polyelinic & & & & \\
\hline No. of Patients & 14,973 & & 6,642 & 5,951 \\
\hline $\mathrm{MCH}$ & & & & \\
\hline $\begin{array}{l}\text { Antenatal } \\
\text { Postnatal } \\
\text { Children }\end{array}$ & 44 & & - & $\begin{array}{l}583 \\
- \\
953\end{array}$ \\
\hline Lab Exams & & & & \\
\hline $\begin{array}{l}\text { TB Sputum } \\
\text { Malaria }\end{array}$ & $\begin{array}{l}278 \\
260\end{array}$ & & - & $\begin{array}{r}64 \\
2,665\end{array}$ \\
\hline
\end{tabular}

1352: Refers to year ended March 20, 1974 
Exhibit 9

Miran Hospital (A)

Sone Data on Basic Health Centers in the Province

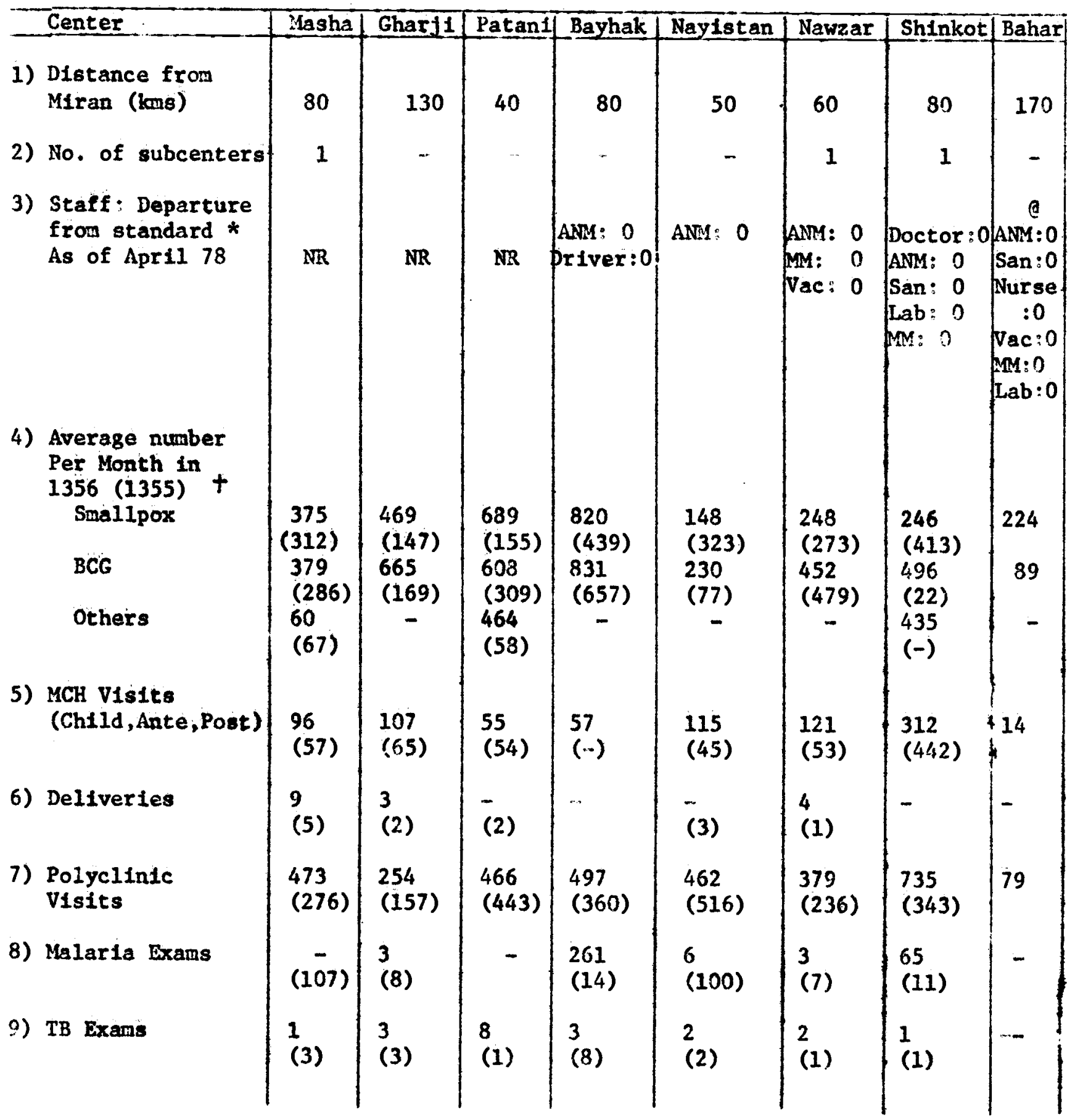


Exhibit 9

Miran Hospital (A)

\begin{tabular}{|c|c|c|c|c|c|c|c|c|}
\hline Center & Masha & Gharji & Patani & Bayhak & Nayistan & Nawzar & Shinkot & Bahan \\
\hline $\begin{array}{l}\text { Mobile Team } \\
\text { BHC Cleanliness } \\
\begin{array}{c}\text { Quality of } \\
\text { Service }\end{array}\end{array}$ & SR & NR & NR & Good & Good & Bad & Bad & NR \\
\hline
\end{tabular}

NR: No Report: ANM: Auxillary Nurse Midwife: MM: Malaria Microscopist:

Vac: Vaccinator: San: Sanftarian: Lab: Laboratory Techniclan

Q As of October 1977

* Standard BHC Staff: Doctor, Nurse, ANM, San, Vac (3), Lab, M, storekeeper, clerk, driver, and peons (3). Figures shown in the columns are actuals where there were departures from standard.

+1356 (1976-77) is based on data for first two quarters. Figures in brackets are for 1355 (1975-76). 
Lanagement Sciences for sealth

Kabul

\section{Mran Hospital (3)}

It is now slightly over two months since I took charge as Provincial Health officer of Miran. I an proud of the fact that the doctors have cooperated with me like brothers. God is great. Things have improved consideraily. There are many more things to do. I think with the cooperation I have had, we will be able to implement all our plans.

Dr. N. Niyazi was reflecting on his charge as Provincial Health officer of Miran. This case describes the steps that he took and the results he had during the two montins. The (A) case describes the situation of prior to November 5, 1977, the day Dr. Niyazi took charge.

\section{Initial Impressions}

Dr. Niyazi explained his initial impressions:

I can only describe the situation I found as one of inertia. Inertla in daily work. The relationship between the doctors and the previous provincial health officer was not good. The doctors felt that the officer was rude. There was no respect for the young specialists. In administration you need good relations. In the absence of such relations, administrative work was just not running smootily. The hospital was not clean.

\section{Observation Report}

Dr. Niyazi described his initial steps:

My first impression of the hospital was not encouraging. on the third day, I formed a team of five doctors from the hospital, including myself and an internist physician. The group visited every part of the hospital that day took stock of the situation and recommended what was needed.

I keep a copy of the group's observation report in my action f1le. I follow up on every item in the report almost daily.

Excenpts from the team's report are given in Exisibit 1. The problems identified ranged from replacing an electric bulb in an inpatient room to the need for more nurses, and fixing the roof of the building.

Case naterial for Management Sciences for health prepared by Dr. K.R. Srtinivasa liurthy. A case is not designed to il
correct or incorrect handing of administrative problems. 


\section{Action}

I keep the report with nle. On the right half are the recornmendations. On the left half $I$ write the steps taken and the results, if any.

For example, I wrote a letter to the Institute of Dentistry on November 10,1977 . I sent ay dentist to get equipment that will work both manualiy and by electricity. Last night I heard that the ministry is sending the equipment with Dr. Qaseem.

Only 15 of the 30 beds were furnished. The other cots were bare. The mattresses were in the store-room. They were not spread on the cots. I got all the beds ready for use.

There was no talephone for the doctor on duty. We identified this problem in our report. Wo got a connection point fixed in the room where the nurse and the doctor stay when on night duty. After 4 p.m. each day the telephone is removed from my office and is fixed in the doctor's duty room. This arrangement did not cost us much money. Some used wire. That is all. There was an old telephone at home. I got it repaired I an now on 2 ; - hour call each day.

To be able to do things I have found the need for understanding a lot of detail in every aspect of our working.

\section{Personnel}

Anotier major task Dr. Niyazl undertook was in the area of personnel.

I save detailed job descriptions to almost all employees. For example, I assigned the cleaning staff specific tasks as also areas of the hospital that they had to keep clean. I posted these job descriptions and task assignments at various places - one in offica, one in the doctor/nurse night duty room and one in each corridor. In the case of some technical staff, I have asked thern to sign one copy and return it to me to make sure they have understood their roles and undertake to fill them.

Some of the job descriptions that were clarified are given in the appendices.

$\begin{array}{cccl}\text { Appendix } & 1 & : & \text { Nurses } \\ " & 2 & : & \text { Auxiliary Nurse Midwife } \\ " & 3 & : & \text { Compounder } \\ & 4 & : & \text { Delegation distribution World Food }\end{array}$




$\begin{array}{rrrl}; & 5 & : & \text { Lab Technician } \\ " & 6 & : & \text { Sanitarian } \\ i & 7 & : & \text { Vaccinator } \\ " & 8 & : & \text { Public Health Nurse } \\ " & 9 & : & \text { Peons } \\ " & 10 & : & \text { Administrative Staff } \\ \Rightarrow & 11 & : & \text { Basic Healti Center Staff }\end{array}$

The head nurse, who also supervised the kitchen, comnented on the posting of job descriptions as follows:

When people are without work, the jow descriptions show what they can do. -

Doctors are educated. They need to be handied differently like colleagues. Even doctors now wear the white aprons. Before I jolned there was no deputy PHO. How we have have one. He handles many queries, signs immunization certificates and heips in nany ways, including visiting basic health centers.

Ever, Wednesday morning we have a meeting. We discuss all problems. Sometimes, we make unofficial arrangements to accomodate personel problems. A doctor cannot stay all through a night when he has night duty. He tells us. We arrange with the nurse so that he could send for the doctor in need. The whole atrosphere is cnanging.

\section{Provincial Governor}

According to Dr. Niyazi, the provincial governor took keen interest in the health activities. Dr. Niyazi explained:

Each night he asks about the doctor on night duty. He wanted to visit the hospital last Ihursday. I have taken some more time so that I can present a better pictura. He is coming the day after tomorrow. He has considerable prestige at the center.

I have requested the Ministry to grant me financial powers to spend up to 10,000 Afghanis within approved budgets. I have not received those powers. I can't buy even a bulb. But I have not missed the powers; my work has not been hampered. I explained to the Governor how I lose my prestige and he loses his time even for small things like purchase of a bulb. He is understanding and supportive. He approves most of our requests quickly. 
Besides the governor, the local newspaper reporters also telephoned Dr. Niyazi to find out the names of the doctor and the nurse on night duty. These names usually appeared in the morning newspaper.

\section{Emergency Supplies}

Dr. Niyazi explained a problem he faced with emergancy suuplies and how he tackled it:

Recently a young man met with an accident and was hospi talised with us. His mother, along with a child, came to see him, her only son. She met with a worse accident. We could not treat her in our hospital because we did not have the necessary emergency facilities, and supplies. "Dr. Tabib, the patients relatives, and $I$ pitched in some money to send her by taxi to the Jamuriat Hospital.

Next, all of us sat down at our weekly Wednesday meeting to discuss what we should do regarding getting emergency medicines. We found a solution. We invited all the 16 pharmacists in the town and asked their help in kind.... Each agreed to contribute different ampules such as ephidrine and aird, worth 500 Afghanis. We are going to keep a cupboard full of these 35 different medicines worth 8,000 Afghanis in the emergency room.

Asked whether such donations would continue after the initial supplies were exhausted, Dr. Niyazi sald:

The pharmacists depend on us for many things. We can twist their arms, if needed.

\section{Floor Plan}

As part of his plars to improve the administration of the hospital Dr. Niyazi implemented a new floor plan which he designed. Dr. Niyazi explained:

I moved the departments with a large number of patients nearer the entrance. For example, the polyclinic was inside and close to the inpatient rooms. I moved the polyclinic to where the administration was, 1.e., at the entrace. Fortunately the administration department, could move out to the new building that was occupied by Sanitation. Sanitation people vacated and went to Kabul. The polyclinic is now closer to the entrance and the crowding of the corridors has been reduced. 
There are hardly one or two patients registering for tuberculosis. The $\mathrm{TB}$ registration was, therefore, moved to where the polyclinic was earlier. Similarly, related departments - Internist, Pediatxics, Surgeon, MCli, Lab

Technician, $X$-Ray were put close to each other.

The World Food Progran distribution center, which distributes milk wheat and oil to pregnant women, children and mothers, was in front of the operation room. We have noved it to a place away frcm the operation room. There is no crowding in front of the operation room. There is a big corridor in front of the operation room. room in it for four recovery rooms. My floor plan did not cost us any money. .... Söme of our time.

\section{Basic Jealth Centers}

During his two months Dr. Niyazi had visited only one of eight basic health centers in his province. Excerpt: from his report which he sent to the Minister are given in Exhibit 2. Dr. Niyazi noted his problem:

Now niy car is cold. It won't start. 'I want a new car. I have written to the Ministry. I want to send detailed job descriptions to the basic health centers also.

Most of the problems of the basic health centers hinge on the relationship between the Woluswali and the health center doctor. The health center doctor has a car while the Woluswall does not. Ofter relations get spoiled when the Woluswali tries to extend his authority and tries to assert that he is the boss for the BHC doctor.

Recently complaints came to the Governor and to me about a basic health center doctor. The complaints were that the doctor did not stay on the job while the patients were waiting. They said he was no good. I and my deputy visited the center separately at two different times. I found that the doctor had gone to a village to attend an emergency case of a woman in labor. Patients were waiting at the center. Woluswali was right from an administrative angle. I arranged an informal meeting of all to sort out the problem.

Sometime: the allegations are false. The governor got one talegram from another Woluswali that people were dying while the doctor did not care. The Woluswali was holding the doctor responsible for anyone dying anywhere in the Woluswal. He expected the doctor to take his instructions on everytining. We had to clear it and inform the Governor of the exact situation and then things settled. 
We have a new jeep not. We can visit the basic health centers more frequently. We sand medicines to them in emergencies. I have sent vaccinators and nurses for temporary duty to the health centers.

\section{iime Allocation}

Dr. Niyazi lescribed his daily routine.

I spend about two hours each morning answering all the letters from the basic health centers and the ministry. I then go around the hospital and visit the patients which takes about an hour. I do get between two and four hours a day for thy private practice. Practice in smaller towns is better than in Kabul for most doctors.

Results

Hospital statistics ware generaliy scanty and most provincial health officers and ministry officiais were skeptical of the accuracy of whatever was available. Available data are given in Lxhibit 3. Dr. Niyazi received monthly reports from each department on the number of patients, lab examinations, atc. There was no format or comparative data for previous perious.

Dr. Niyazi reflected on the results.

I would say we are sti11 in the experimental phase. I have reason to be satisfied though about tha results so far. Some surgery equipment has come. We got a new jeep, new sheets, and blankets for all the beds. Je repaired one room for patients and prepared one for recovery. We have new rooms for the vaccinator, $M C H$, Food Distribution and for the doctors. All these vare achieved witil little additional resources but a lot of cooperation from doctors, staff, Governor and the ifinistry. For example we set up a new room for my deputy. Te furnished it by removing some of the furniture in various doctors' rooms. The doctors have willingly cooperated. I have promised to put in a request for the needed furniture in the 1357 budget. But effective work has not been hampered for want of furniture oudget or purchase formalities.

According to plan, we should have dug 50 shallow wells. only thirty were complated when I came. I insisted that the remaining twenty be completed. They said it was cold. I insisted. All 50 are now coinplete. 
Let re give you another example. The peon we have prom vided in the $X$-Ray room was our gardener. Now it is winter. We don't need a gardener. By next year I hope our request for a peon will be granted.

I have more plars riatch I have given to the Governor. He is working on them.

Manaing the Change

Dr. Niyazi reflected on the introduction of change

I have had very little resistance. The staff like the changes. They get graater satisfaction, One reason maybe that someone is noticing what they do and what they don't. I guess it gives them a sense of importance, a feeling that an officer cares awout their work. Another reason might be that there are explicit procedures and all are treated equally. Earlier some did the work according to prescribed roles while some enjoyed. The inequities led to lowering the importance of doing one's vork. Things have changed a bit here. But I cannot complain of any resistance.

An internist doctor commented on the changes:

There has been an improvement in management here. Earlier the Provincial Health officer aither did not care or did not understand the proulems. We would take many points to him repeatedly but hardly anything was done. Now, Dr. Niyazi is different. He is taking action. Hanagement has improved. But we have to gat a lot nore equipment and some doctors befora we can compare oursalves to the better hospitals.

the changes:

Dr. Niyazi comnanted as follows on what helped hin in accomplishing

Firstly, the ministry has given us importance. The .. Governor has taken keen intarest. Secondly, my own experience has helped we. When I was young I thought if one had friendly relations witi the Governor nothing else was required. Now I know better. Support and cooperation is needed from many people - the ministry, doctors, staff etc. If somebody did not do work I used to quarrel with him. Now I try to understand the problems of the subordinate and his reasons. I try to solve them and get work done. I an more successful now than before. A friendship enviroanent is needed. Another thing that experience has taught me is what to ask from whom. 
Earlier I would ask big things from small people. Now I know whom to ask for anything I need and how to justify my request. I am interested in doing good work that is what I think supports you in doing so, One should not thini that everything is black and white. Everyone I have sougint help from has helped me.. Finance Ministry, senior administration clerks, everyone. In Afginan culture, if you respect them, they will respect you. 


\author{
Exhibit 1 \\ Miran Hospital (U)
} Excerpts from the report of the team of five hospital doctors that took
stock on 22-8-1356

1. Matters related to Medical Equipment

1.1 Dental clinic needs a machine (Letter, 24-8-1356; Hospital dentist asked to follow up with Dental Presidency).

1.2 Laboratory needs equipment (Head asked to submit a list; Letter 25-8-1356; An assistant was sent to National Laboratory Institute,
Kabu1).

$1.3 \mathrm{X}$-ray machine wiring and table needs repair (Repaired; 28-9-13556).

1.4 A table and electric coll are needed in X-ray film washing room.

1.5 One operation table is not working (A table and related supplies such as suction machine, tray, and intestinal tube were brought from central stock by one of the doctors).

1.6 The generator is consuming three gallons of fuel per hour against two earlier. Needs examination.

2. Matters related to office Equipment and Furnishings

2.1 Telephone facility is needed in the night duty room for the doctor and the nurse (Provided: $6-9-1356$ ).

2.2 Gowns in the oparation room are dirty (Cleaned).

2.3 The Deputy Minister has promised a kerosene stove for the operation room. This needs to be pursued.

2.4 Curtains are needed in doctors' rooms.

Note: Matters on which some action had been taken are circled and the action is shown in parentheses. 
Exhibit 1 (cont'd)

Miran Hospital (B)

3. Matters ralated to Buildings and Haintenance

3.1 Kitchen reeds cleaning (cleared: 25-8-1356).

3.2 The wall in the $\mathrm{X}$-ray room needs repair.

3.3 Latrine jeeds repair. The wiring in the first floor bathroon needs repair. The bathroom walls need plastering and painting.

3.4 The ceiling in the first room has cracked and that of the second room had fallen domn. (Second room ceiling fixed: -9-1356).

3.5 Electrical switches and wires need maintenance. The bulb in patient roon 3 has to be repiaced.

3.6 An isolation room is needed for patients with communicable diseases.

4. Hatters related to Personnel

4.1 The laboratory needs an assistant.

4.2 A peon is needed for the X-ray room (Assigned: 12-10-1356).

4.3 The position of the nurse who was transferred needs to be filled. Shortage of nurses needs correction.

4.4 The six patients in room 15 have not been visited since 19-3-1356.

5. Hatters related to storage

5.1 Decisions are needed on (i) a few smuggled antibiotics in the drug storeroom, and (if) supplies in room 1 that cannot be used (could be auctioned).

5.2 Orderly storage and cleanliness are needed. Offica furniture are scattered in storeroom 2 .

5.3 Only milk powcer is available in the World Food Program. Wheat and shortering need to be ordered. 
Exinibit 2

Miran Zospital (B)

\section{Excerpts from a Report on the Patani Basic Jealth Center}

Otservation report of Dr. Niyazi, Public Health officer from the Basic Health Center of Patani.

Dear Minister of Puilic Health -

On 12-9-1356 I, Dr. Hohamad Niyazi, observed the Basic Health Center of Patani. ilere is the report of ny observation.

1. Dr. Hamed came to work at $11: 00$. Then I asked him why he was so late his reply was that he went to a village to help an exergency delivery. Then the head of the Basic Health Center was told to se sure to refer patients to the health center durling official working hours.

2. The adainistrative employee was not present in his job. According to the head of the halth center he went to the Public Health office for some official business. Anyway, he was markad absent.

3. Mr. Dadmohammad, Assistant to the Laboratory, was not pressnt in his job. He vas marked absent.

4. Mussa, the nurse, and the vaccinator of the center have been transferred but no replacenents yet. Hope the Ministry authority will pay spectal attention to the replacements for the nurse and vaccinator.

5. Mohammad Fazel, the sanitarian, was not present in his job. He was marked absent.

6. There weren't enough WFP supplies at the center. Kope that the WIF Dept. sends some more foodstuffs to the center.

7. There weren't any healtii cards at the health center. The head of the health center was instructed to inform the finistry and ask them to provide heaitis cards fox the health centers.

8. According to the organization of the Basic kealth Center there is a subcenter at sajawand. The head of the center was instructed to contact hinistry authority, provide supplies for the sub-center, and then assign soneone to receive the provided supplies.

9. There $\operatorname{wasn}^{3} t$ a register book for vaccination. The vaccirator was instructed to get such a book so that he could easily figure out the vaccination activities from that book. 
10. As the head of the health center indicated, there is not an official seal for the health center. Hope that the Ministry could provide this health center with a seal.

11. A person by the name of $\mathrm{Zla}$ is working th the potable water project of the Environmental program. According to the head of the health center, this person does not receive a salary. Fope that the Environmental health department of the Hinistry takes necessary action regarding the issue.

12. The oil of the water pump was not changed. Afizullah, the head of the Environmental Program, was Instructed to be careful in this regard so that there won't be any damage to the vater pump.

13. A lot of empty cans were scattered all over in a room. Instruction was given to remove those cans and keep the roon clean. 
Exhibit 3

Miran Hospital (B)

Some Data On Hospital Activities

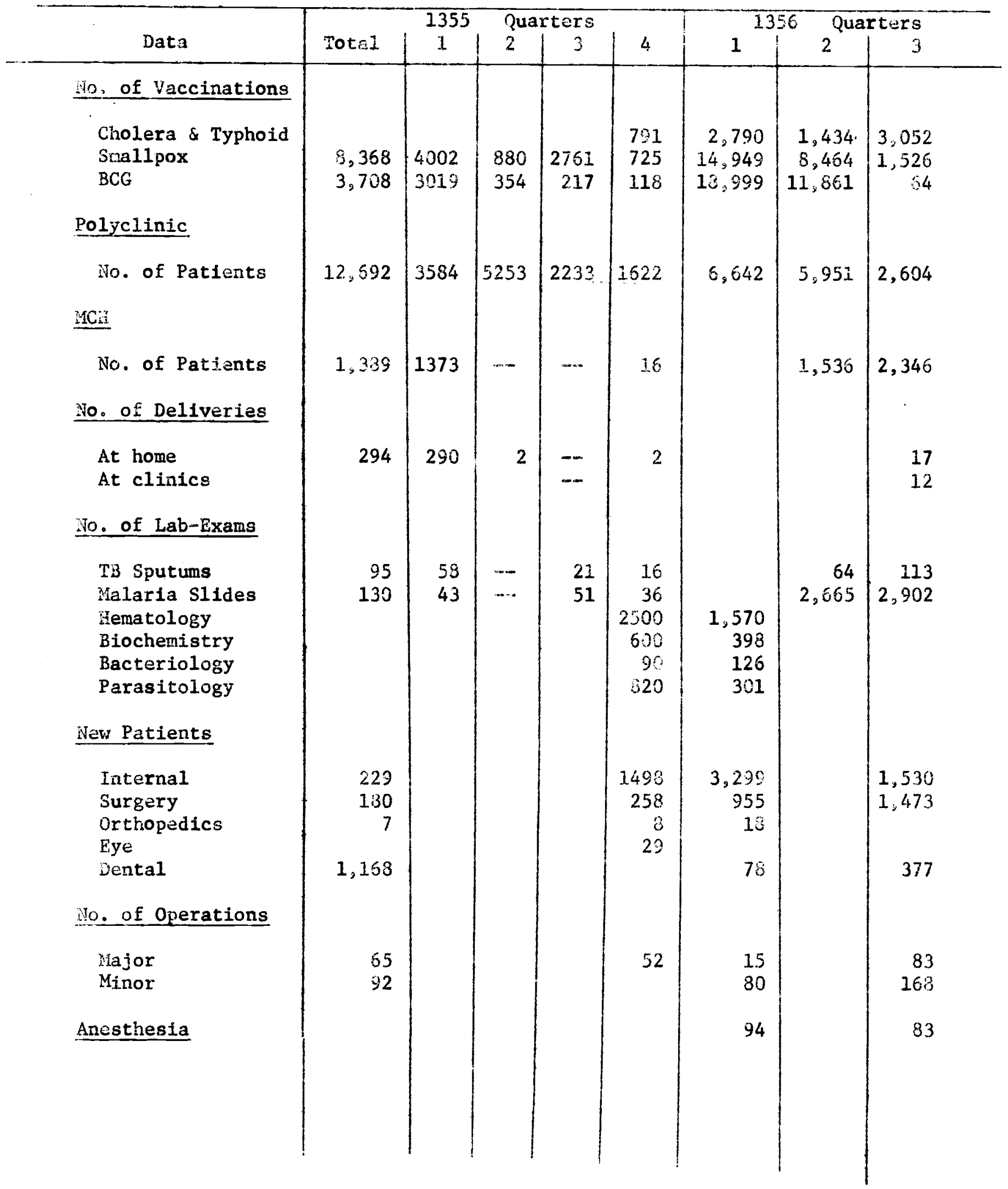


Exhibit 3 (cont $^{\circ} d$ )

Miran Gospital (B)

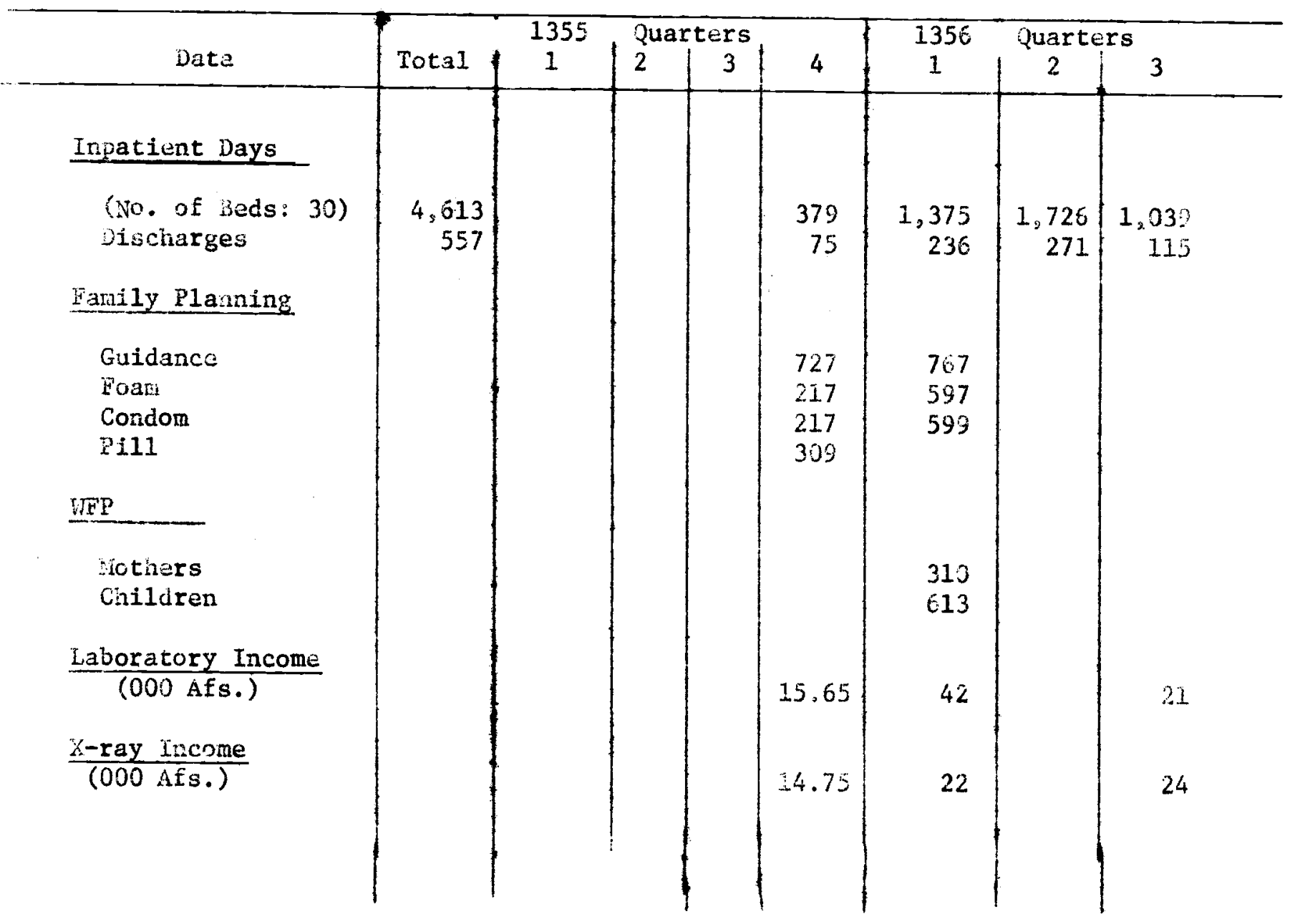




\author{
Appendix 1 \\ Miran Hospital (B)
}

\title{
Job Description for iNurses
}

Dear Mr. Naseem, the head nurse, Mr. Gulam, the nurse, Karima and Sajida, the nurses for public health office -

Plase keep the following things in mind:

1. By taking turns, you should be present in the hospltal for 24 hours . and should not leave without permission.

2. After the official working hour take the telephone to the roon of the person who is on duty. The telephone should bu there at right.

3. If a patient is not doing fine, this snould be reported to the concernei doctor.

4. Get the patient racord forms ready immediately.

5. The prescription should be immediately written by the doctor and the drugs should be administered right away.

6. The temperature, pressure, and puise of the patient should be taken right away.

7. The patient's food should be checked.

3. The expenditure should be recorded appropriately.

9. The patient's clothes should be clean.

10. The room of the patient inside the hospital and around the hospital should be kept clean.

11. The lights should be lit after the electricity is off.

12. Emergency patients should be hospitalized itmediately and the doctors should be informed.

13. The person who is on duty should have his food (dinner) at the duty room not anywhere alse.

14. The person who is on duty cannot go to his own house on the night he is on duty.

15. Surgery patients should be dressed before 8:00 A.M. 
Appendix 2

Miran Hospital (B)

\section{Job Description of Auxiliary Nurse Midwife}

A. At the Basic \& Sub-Centers:

1. Light treatments, first-aid

Finding out people tho have contagious diseases, i.e. TB and malaria. Giving injections and doing dressings based on the instructions of the doctor.

2. Doing things related to deliveries and child clinic.

3. To help doctors at the clinic.

4. To take care of the children who have had smallpox and BCG vaccinations,

5. To keep and prepare registration records of children and pregnant woman.

6. To weigh children and pregnant women, listan to their complaints, and refer pregnant women to concerned doctors for examination.

B. In the Field:

To do home visiting for the following purposes:

1. To encourage prognant wonen to go to the clinic.

2. Possibilities of having normal delivery at home.

3. Health education and proper guidance regarding prevention and mother health.

4. To examine those momen who are pregnant and cannot come to the clinic.

5. To encourage dais (traditional jirti attendants) to come to the healtin center and learn new and healthy techniques of delivery.

E. Find out reasons why pregnant women don't go to the clinics.

7. To help with normal deliveries.

8. To nurse after the delivery.

9. Practical guidance to nothers about nutrition, supervision and health care of children under five years.

10. To find out people who have contagious diseases - especially malaria and tuberculosis. 
Appendix 2 (cont'd)

Miran Zospital (B)

Job Description of Auxiliary Nurse Midwife

11. To supervise those who have had smallpox vaccination for the last 3 years. Also, to give BCG vaccine to those who are under 20 .

12. To keep the records and home visit forms.

13. To utilize and keep clean the operation boxes.

14. To record registration of deliveries done by ker.

15. Fresenting information immediately about the existence of contagious diseases in a village. 
Appendix 3

Miran kiospital (B)

Job Description of the Compounder

Duties of the Compounder at the Health Center.

i. Should keep the pharmacy clean.

2. Should use alphabet to arrange drugs.

3. Shelves should be specified separately.

4. A book should be kept for the total drugs and the amount spent.

5. Drugs which are sensitive to the light and sunshine should be kept in appropriate and dark placas.

6 Dafly prescriptions, especially important ones, should be filled daily. Also daily consumption of drugs should be immediately requested. The compoundar is having an important role in this case.

7. While making solutions the compounder should use bolled water if any other sterilized water is not available.

0. The compounder should keep the emergency drugs completely.

- He should be aware of all administrative rules and regulations related to his job.

10. If he is responsible for WFP, he should know all rules, regulations and procedures. 


\section{Appendix 4 \\ Miran Hospital}

(B)

Job Description for the Delegacion Distributing World Food Materials

Duttes of the delegation who distribute WFP.

Those who are assigned to oring WFP from the inistry Depot.

1. The WFP should be received from the Distribution office of WFE.

2. The delegation is responsible not to receive bags of WFP whici are having holes and the amount of WFI is already taken out. The bags should be weighed first and the amount is aissing should be noted.

3. The delegation should put the JFP into the car properly -. when it gets to the health canter it should be counted and put into the store in the presence of a delegation.

The Responsibilities of the delegation at the Healtin Center and S.C.

1. Whenever the delegation opens the door of the store, it should be made certain that the seal and signatures on the door have not bcen removed.

2. After locking the door of the store roon, the door should be sealed, signed and then glued.

3. The delegation should distribute the WFP properly to those who have coupons. Husband's name, date of distriuution, and the signature or fingerprint of the person who is recaiving the WFP should be recorded in the book.

4. The delegation should often check that people who receive WEP leave the compound of the hospital with WFP.

5. The delegation should not keap in the store or in the office any material on behalf of the recipients. Recipients should be asked to take the materials immediately.

6. The delegation should ensure that no one brings and uses two coupons. If such a thing happens, one coupon should be discarded. Also, if the two coupons have been used for a long time, then voth coupons should be kept. Not only the head of the health center be informed about the issue but the mattar should be written in the WFP regulation book. 
Appendix 5

Miran Hospital (B)

Job Description for Lab Technician

1. Doing laboratory exams - might be asked officially and written by the concerned doctor. Laboratory exams such as urine, albumin, glucose, determining the amount of hemoglobin in blood, direct exam of sputum, and stool cxam.

2. Carefully recording the results into the exain card, e. 6 . date that the exain was asked, dat 2 that result was givea, and the signature of the person who examined.

3. Recording it on the family card.

4. Preparing dajly report.

5. Sending the material and referring the patient to the appropriate place if lat exans are not possible.

6. Taking blood slides of those who have maiaria.

7. Sunding the blood slides to be examined to the malaria units.

¿. Completion of coloring materials and standards consumed.

S. Kceping $1 \mathrm{ab}$ equipment and room clean.

10. The registration of each test done at the lab. 


\author{
Appendix 6 \\ Miran Hospital (B) \\ Job Description of Sanitarian
}

The entire region will be divided into segments. For each segment a sanitarian will be made responsible for the following activiteis:

1. Application of all environmental affairs under tìe supervision of tile health center doetor...

2. Should be familiar with his own geographical area. Jumber of houses, name of the head of each house, number of people living in a house, their sex, drinking water sources, latrines.

3. On the map of that area, crowded places, communication lines and streets should be marked.

4. Providing health education and finding out ways to prevent contagious diseases.

5. Halp people with provision of safe wells, installing hand pump and their maintenance.........

6. Collecting water samples from sources where people gat their drinking water. This should be done based on the instruction of the concerned office for laboratory exams.

7. Cooperating with paole in bullding clean and proper latrines.

3. Supervision of shops, tea houses, samovars, public bathroons, and schools.

9. Giving reports immediately to the head of the health center regarding contagious diseases and quarantine.

10. Cooperation with other personnel to prevent and control diseases.

11. If possible, providing health cards for the houses and shops.

12. Providing and presenting daily as well as monthly reports to the head of the center. 
Appendix 7

Miran Hospital (B)

Jot Description of the Vaccinator

1. To keep all the vaccines safe $e . g$. keeping $B C G$ vaccine in the refrigerator.

2. To distribute vaccines in a technical correct way to the vaccinators of subcenters.

3. To keep appropriately all vaccination supplies e.g. needles, syringes, etc.

4. Administration of smallpox $3 C G$ and other vaccines to mothers and children at the center in the clinic.

5. To make home visits and give appropriate vaccines to children under three years. Also to give smalipox vaccines.

0 . Receiving daily as well as weekly reports from the vaccinators of subcontractors.

7. To prepare monthly reports based on the weekly reports received from the sub-centers.

8. To supervise activities of the vaccinators working at the subcenters and guide them for proper vaccinations.

9. To guide vaccinators of subcenters in preparation and submission of dally as well as monthly reports.

10. To guide vaccinators of subcenters ho: to keep vaccines and vaccination supplies. 
Appendix 8

Hiran Hospital (B)

Job Description of Public Health Nurse

1. Is responsible for administering nursing services.

2. Participating with other fmportant health team members to extend health services.

3. Helping nursing personnel to solve problems.

4. Collecting reports from the field and proparing monthly reports.

5. Doing home visiting including nursing.

6. Helping other health team members on training programs.

7. Executing jobs in mother/child care and promoting family planning programs.

8. Inspecting uniforms and gowns of health workers.

9. Supervising daily registration, children, deliveries, and provision of forms, etc. 
Appendix 9

Miran Mospital (B)

Job Descriptions and Assignments for Peons

List of the peons and the responsibilities of each. Miran PHO - work starts at $7: 30 \mathrm{a} . \mathrm{m}$.

Name

1. Humayun

2. Shah Nawaz

3. Fatima

4. Nazir

5. Khan

6. Agha

7. Sahir

8. Hyder

9. Z1a

10. Sultan

11. Adam

12. Bashir

13. Rasool

14. Omar

15. Ibrahim

16. Esa

17. Ismail Zadeh

18. Magul

19. Akbar

20. Naim

21. Abdullah
Main Job

Internal service Surgery service Female halls

Cilild cinic

Latoratory

Dental clinic

Interne1

Pharmacy

Gardner

Cook

Asst. cook

Guard

is

Admin. Peon

PHO $\because$

Asst. to

storeroom keeper

oper. roon peon

Launderer

Barber

Mechanic (pump)

II cook

\section{Responsibilities}

cleaning patients room, hall and clothes clothes, rooms and hall female hall \& clothes the whole hall windows, mirrors, \& front hall halls \& glasses int $=$ rnal room \& washing roon iasin hall \& pharmacy hall all $X$-ray rooms kitchen and patients food "1 "all dishes hospital including garden grounds in the holidays as above admin. office, hall \& taking lettexs

Pio's office \& washing glasses the store room with the storeroom keeper operation room \& dressings Should always be in the hospital \& take clothes

Should see patients every day

Should keep the machines clean \& operative

Besides his job, keeping vaccine $\leqslant$ is rooins clean

List of peons at the Pilo -

\begin{tabular}{|c|c|c|c|c|c|c|c|}
\hline Name & Duty & Week Days & Chopping & wood & at & women's & hospital \\
\hline 1. Nazir & to bring mater & Sat. & Chopping & wood & at & women 's & hospital \\
\hline $\begin{array}{l}\text { 2. Kuan } \\
\text { 3. Agha }\end{array}$ & $\therefore$ & ron. & $n$ & $\because$ & $\pi$ & is & $\because n$ \\
\hline 4. Sahir & $n$ & Tues. & $\because$ & $\because$ & $a$ & is & 18 \\
\hline Hyder & $\because$ & vied. & is & in & $\therefore:$ & it & ir \\
\hline Zi3 & $\therefore$ & Thurs. & ir & $\because$ & $\because$ & is & is \\
\hline 7. Bashir & i: & Fri. & $\therefore$ & 18 & $"$ & is & if \\
\hline 8. Rasool & $: i$ & Sat. & is & $n$ & $\because$ & $"$ & 98 \\
\hline
\end{tabular}


Appendix 10

Miran Hospital (B)

Job Assignments for Administrative Staff

I Amanullah -. Admin. Clerk

1. Doing secretary work

2. Doing attendance

3. Salaries

4. Euel

5. Maintenance

6. To supervise peons

7. Other admin. tasks

II Waheed - Property Clerk

1. Handling the affairs of the storeroom keeper

2. Handling the affairs of the nurses

3. Recording traffic incidents

4. Handling the affairs of WFP and pharmacies

5. Handiing the affairs of the driver and iaspector

6. Handling the affairs of people tho hav responsibilities

III Dad-i-Khode -. Ioad Clerk

1. Jandiing salaries, accounting, transfers, etc.

2. Handling allocations and the expenditures

3. Helping in other admin affairs

IV Anwar - Admin. Clork

1. Receiving and 1ssuing letters and arrangement of documents

2. Specifying files during emergency e.g.: duty files, files for contagious diseases, quarantines, etc.

3. Supervising geons sealing or signing register book

V Shah - Property clerk

1. Handling and operating storerooms in accordance with rules

2. Handing food for patients

3. Regular depositing money to the bank, giving bill to the clinics at $1 \mathrm{ab}$ exams and $\mathrm{X}$-rays

VI Fakrudin - The Typist

1. To type all letters, proposals, reports, list of people who are on duty, Dharnacies, and the list of the doctors who work free for the Red Cross Society 


\section{Append 1x 11 \\ Miran Hospital (B) \\ Responsibilities of Administrative and Technical Personnel of the Health Center}

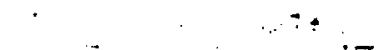

\section{Head of the Health Center}

1. Inplementation, supervision and evaluation of different offices programs of basic and sub-centers. The program includes mother/child health, environmental health, control of contagious diseases, family health and treatment of patients with the cooperation of other doctors and personnel.

2. Determining regions for each nurse, vaccinator, and auxiliary nurse midwives.

3. To study births and deaths, existence of contaglous diseases and plan to prevent them.

4. To set up programs and deteruline personnel duties in different offices of the center.

5. Determining home visiting programs for thi personnel of basic and subcenters with the cooperation of the sacond doctor of the center.

3. Doing mother/child care and treatment of common diseases according to the progran of the health center including distribution of WFP.

7. Supervision of administrative and financial affairs.

3. To supervise sub-centers and howe visiting personnel in the field.

3. To control and stidy activity reports of differcat offices of the center and then these reports to the related presidencies of the ministry.

10. Fresenting proposals to the president of public health regarding improvement of programs.

11. To guide personnel on the job based on the policies of the Ministry of Public Health. 


\author{
Appendix 11 (Continued) \\ Miran Lospital (B) \\ Responsibilities of Administrative and Technical \\ Personnel of the Health Center
}

Second Doctor of the Bealth Center

1. To do things related to child/health care, daily treatments, environmental health, control of contagious diseases in the area based on the set programs.

2. To supervise nurse, nurse-midwives and vaccinators while dotng home visiting.

3. To study deaths and births, finding out contagious diseases and prevent them at the center and at the attached submcenters.

4. To study and control activity reports of the personnel on the field and then presenting these reports to the head of the health center.

5. To guide santtarians, nurses, vaccinators and other para-medical personnel to do their duties based on the polictes of the Ministry of Public Health.

6. To guide personnel on how to use forms correctly.

7. To do health propaganda not only to the people but to the health personnel too.

Duties of the Dental Doctor

The dental doctor is responsible for treating dental diseases of people

who come to him. He should also try to provide facilities so that he could fill the teeth of patients. 
Teaching Notes on Kataghan llospital

Case Abstract: The Kataghan Hospital case describes a Provinclal Health Office and the problems faced by its officer, Dr. Hasan All Mahnud. The office work is "tiring", says Dr. "Yahmud, an obstetriclan/gynecologist. The problems mentioned by the officer are in the areas of managing nurses, unauthorized absenteelom among nurses, constraining governmental regulations on purchase, and lack of delegation. The case provides brief notes on the budgeting process and the Afghan civil service regulations. The case also gives the actual budget proposals of the PHO and the action taken at the Presidency of Curative Medicine. The case can be used to evaluate the budgeting process, the actual proposals and action taken, the quality of supervision of Kataghan Hospital and of the Basic Health Centers. The case provides available statistics on the activities of the hospital and the BHCs. The inputs provided and the quantity and quality of outputs of the hospital and the BHCs can be related and compared.

\section{Teaching Objectives:}

(1) Improve particlpant skills in managing personnel and tackling the problem of absenteeism.

(2) Improve the ab1lity of particlpants to prepare better budget proposals - budgets that reflect more accurately the priorfty needs of the hospital and the province.

(3) Bulld, anong the participants, an attitude of a manager accepting responsibility, of a confidence that things can be changed to bring about improvements: (i) within the regulations of the government and (11) in those with the necessary powers who deal with the PHO and his needs (there 1s of ten a great deal of difference between regulations and their application; the PHO can of ten Influence the practice to his/his hospital's advantage if not the regulations themselves,)

(4) Push towards a job behavior in which the PHO acts as a manager, directs the staff, enforces leave regulations, takes action against unauthorized absenteelern, understands and helps solve genuine problems of employees, and expects decent job perfor. mance from everyone in the hospital and the Basic Health Centers.

In any one discussion, not all of the objectives can be covered. The aspects covered and the depth of coverage would depend on the backgrounds of participants, the time allotted for discussion, and the Instructor's objectives. 
The case can be used for discussion among provincial health officers, basic health center doctors and Ministry officlals in charge of evaluating hospital administration. It can be used in courses on general management, budgeting and control, and personnel management.

\section{Discussion Questions}

Instructors may find it useful to pose the following discussion questions:

(1) What do you think of Kataghan Hospital and Dr. Mahmud as a Provincial Health Officer? In what areas is Dr. Mahmud facing problems and why?

(2) If you were the Provinclal Health officer, how would you (i) manage the hospital, and (ii) supervise the Basic Health Centers?

(3) Within the given govermmental regulations, how can Dr. Mahmud ensure better attendance and work (1) of nurses, and (ii) of others?

(4) What is your evaluation of the budgeting process and the budget proposals put up by Kataghan Hospital to the Minister? How well do they reflect the needs/priorities of Rataghan Hospital?

(5) How would you, as the PHO of Kataghan, ensure that your priorities are properly reflected in the final budgets that the Ministry will approve for Kataghan? What are the perspectives of the various Presidencles in Kabul?

(6) In your role as a $\mathrm{PHO}$, what cooperation do you need from the varfous authorities at the provincial and central levels? How would you go about establishing proper relations to enlist the needed cooperation?

(7) How should the PHO plan and allocate his time? Would he need more time to organize his office? How can he reduce the demands on his time? Would you have to reduce private practice?

These questions are briefly discussed below.

Readings: Participants could be asked to read a section/chapter from Koont $z$ and $0^{\prime}$ Donnel1's Management or Peter Drucker's Practice of Managenent or Effective Executive. The section chosen could be on management (who is a manager?) or on a specific topic such as budgeting. K. $R$. Andrews discussion on generalists vs. specialists in his book Concept of Corporate Strategy, or a chapter from Marvin Bower's The Will to Manage may also be good readings for concepts. 
Notes for Discussion

The following notes are alds to the instructors. They are neither intended as criticisms of individuals nor are offered as solutions. They have to be used to post questions and provoke participant 's thoughts on the managerial 1ssues involved. These notes should not be forced on the participants, nor should they be presented as the correct set of solutions. Different opinions should be encouraged. By raising a series of relevant questions and by marshalling case facts, different opinions, and participant experiences, the instructor has to guide the discussion towards a way of thinking about management. Each participant should get a feel for what he might do or should do if he were in Dr. Mahmud's place.

The physical facilities of Kataghan Hospital are in bad shape. The maintenance of both buildings and equipment is poor. There is a shortage of space.

At least a few nurses need to be disciplined. The premises are not clean. Doctors - Dr. Aziz in particular - appear frustrated.

The vaccinations, polyclinic attendances, and other major/minor cases handled by the hospital do not appear comensurate with the size of its staff. If one compares the output per employee with that of some of the basic health centers of the province, Kataghan Hospital fares poorly. After establishing these, the discussion can focus on how $\mathrm{Dr}$. Mahmud should go about solving the problems.

What is Dr. Mahmud's style? Dr. Mahmud is still operating like a doctor. He is not yet behaving like an administrator. He will soon lose his command with his employees. Merely giving Dr. Mahnud a deputy may not solve the problem. The deputy would look for guldance to the PHO. If the deputy is effective in influencing the employees at Kataghan, then interpersonal differences are likely to arise among doctors. If the deputy is ineffective, this PHO at least would be unable to guide him. If the deputy is not a doctor, the problems can get even more compounded and difficult.

There is no doubt that Dr. Ilahmud has to take a managerial interest if he is to remain an effective PHO. For achieving results, the PHO has to act as a manager.

Is Dr. Mahmud facing problems because of constraining governmental regulations or because he has not acquired a reputation as a manager? If the former, then what has Dr. Mahmud done regarding leave, attendance, etc., which are solely the responsibility of the PHO and not of Kabul? If one takes the polyclinic visits, the occupancy rate and the quality of service Into account, one can argue that Kataghan Hospital is overstaffed, especially with nurses and doctors. Are they allocated properly? Can they be pushed to do more work? How? Are the three untrained nurses 
being used effectively as understudies? Can the PHO not reprimand one errant nurse, take stern action and establish a record? What will its effects be on other nurses; on the reputation of $\mathrm{Dr}$. Mahmud as a manager? Can he not rearrange the space and squeeze a little to get a room for the night nurse? That would show that $\mathrm{Dr}$. Mahmud is concerned about results, not in blaning. Dr. Mahnud did not know about the lack of glasses or teapots, an irritating, if trivial problem of the nurses. The nurses do not seem to care about problems of lack of space. The problems have not been discussed. Can there be some creative solutions? of course, some work and some rearrangements are necessary, but no attempts at joint thinking are in evidence. Distant Kabul can always be blamed.

of course, everything is not perfect at Kabul. The Ministry is not geared to Identify and solve the local problems, although it has nost of the powers in personnel and finance. The discussion could be focused on the evaluation of the budgeting process, especially if participants are Ministry officials.

The Ministry's budgeting process can stand improvement. The Minister of Public Health and the Presidencies go through an elaborate budgeting exercise without even a vague Idea from the Ministry of Finance about the extent of finances available for health the next year. The whole exercise is repeated after the extent of avallability of resources 18 known. Since the Ministry of Public Health knows that finances are not unlimited, it can establish some priorities and cuts at the right places. These priorities would have to be both for the Ministry as a whole as well as for each province. For the Ministry as a whole, the revenue budget priority for a particular year could be maintenance of bulldings or addition of minor equipment or increased effort in specific health areas. Ministry wide output or quality objectives have to be established for each year. What does the Ministry want to achieve in 1977-78? In what way would that be different from that in 1976-77? Only with such conceptual clarity can proper allocation of resources to individual hospitals and health centers be ensured.

The current Ministry approach is to ask for as much as possible initially, and allocate what it gets. It is difficult to know how good a job has been done. The budgeting is only for expenditure. There is no corresponding budgeting for performance - in the area of vaccinations, disease control, number of new wells or old ones to be chlorinated, increase in occupancy rate, improvement in quality of service, or reduction in needless flow of patients fron the provinces to Kabul or from villages to provincial capitals. The Ministry has to lay down such objectives, decide on what priorities it wants to assign for each region or type of service for any budget year, estimate how much it would cost and decide how it wants to measure its achievements. This requires putting together available data, visit reports, complaints and opinions about hospitals and health centers in a region, making a comparison among then and informed judgements on what is feasible. 
The budgeting emphasis at present is totally on personnel, and without relating personnel and output. Why does Kataghan need nore staff, especially doctors and nurses? The number of vaccinations per vaccinator In Kataghan Hospital is less than in the Turk BHC. Polyclinic attendances in Kataghan are less than in Kapula BHC. These two BHCs have only one nurse and one AlM each. The 30-bed hospital has only 57 percent occupancy. No dellvery cases are accepted at night and the quality of service is poor. Of course, the data are not rellable. While staffing standards are based on international quality levels, the service levels are nowhere near then. In any case, are staff additions the correct priority? Has there been such an unusually increased turnout of patients and/or improvement in quality? Can some alternatives to solving the problem of space be generated and evaluated? There are only 26 provincial health officers. Can't the PHO and his administrative director be requested to come to Kabul with all budget documents, estimates and justification, and discuss their budget proposals and performance targets? They could spend half a day per PHO. The linistry officials, Presidents of Curative and Preventive Medicine, Adninistration, Planning and Nursing could pool all their data and knowledge and constructively and jointly discuss alternative ways of Improving services in Kataghan within the Ministry priorities and constraints. Can they not agree with the PHO on a set of prioritles, targets and communicate to each other their expectations and set them down so that actual performance can be evaluated against agreed-upon targets?

The interaction between the Ministry and PHOs is now unidimensional and individualized. Each employee fends for himself by contacting Kabul and ensuring his own favorable evaluation, transfer and promotion. The decisions at Kabul are taken in a subjective and impressionistic way. They may be reasonable, but they do not necessarily help improve performance. Kataghan is a case in point. Discussion could focus on how Ministry action on budget proposals of Kataghan would help Kataghan Hospital. All policies, priorities and allocation of resources including promotion and transfers should be based on and geared to only one overall objective better health care delivery in Afghanistan. The Curative Presidency's $s$ action on Kataghan's budget proposals do not reflect any direct relation $n$ to such performance by kataghan llospital.

Kataghan"s budget proposals reflect the lack of thinking about local solutions to local problems. Nor have well thought out, well worked out proposals been submitted to Kabul where local solutions are inadequate. Space is the biggest problem, yet, all that the budget proposals have to say on space is that Kabul may look into the problem. Kabul has a hundred other things to look into. If space is a priority problem, what thinking has Kataghan done to solve 1t? Aren't there any temporary and inexpensive solutions? What are the cost estimates? Shouldn't they be provided to Kabul? Have the suggested solutions been discussed with the Governor? With Ministry officials in Kabul? Have they been invited to take a look? Has Dr. Mahnud vistted Kabul to talk about the Kataghan Hospital/Province problems as opposed to personal problems? Kabul has 
no Idea of the specifics of Kataghan and Dr. Nahmud had not Impressed upon Ministry officials what needs to be done Immediately. He has not ensured that the budget proposals and final budgets reflect the priorities of his hospital, patients and doctors.

The budget proposals are mostly about personnel, promottons and addi $\cdots$ tions. The administrative director has been busy selling his case for a promotion. The Ministry has approved many personnel promotions not sought by the PHO. Why? Does the Ministry respond to personal pressures or problem areas? Kataghan does not need more personnel. It needs equipment, maintenance and supervision. If proper priortties have to be secured for the correct areas, the PHO has to do spade work and canvass support.

The PHO does not necessarily have to do it all. He can put the administrative director, the doctors and nurses to work. All he needs to do is to put down what he wants done (a time-bound progran), break it down by each individual and time perlod. He can have neetings, develop solu.. tions and nominate from anong the staff the responsibility for getting things done. He can change the whole morale of the place. Once staff knows that the PHO Is tough and expects work, many will fall in 1 ine. For all this, of course, the PHO should want to do something about things and take responsibility He will have assistance. He will have things to talk about with the Governor and with Ministry officials. He need not be blaming and complaining.

Discussion can focus on whether all this would take more of Dr. Mahmud's time. Initially may be, but more than the amount of time the type of supervision over other things is important. If $\mathrm{Dr}$. Mahnud can specify what he vants done and assigns it to someone, he will only have to follow up. When the staff knows that Dr. Mahmud won't let up, things will happen.

Once he gets the systems going and the employee morale is Improved, Dr. Mahnud will have nore time than at present for his professional practice, both public and private. It will be less "tiring". The solution to Dr. Mahnud's problems is good managenent, not the lack of managenent or apportioning blame. He will have a good reputation in the hospital and proper relationships with the Governor and Ministry officlals. 
Case Abstracts: Miran (A) describes the position of the Miran Provincial Hospital as of November 1977. There is a general dissatisfaction at the Ministry with the situation in Miran. The case describes the organization of the Ministry, the role relationship of the PHO, the job description off a PHO, the Miran hospital organization, the Basic Health Centers, and the data on their activities. The Ministry, responding to complaints from the staff, fron the Governor, and probably from others, appears dissatisfied with the hospital and the Curative Presidency" handling of the Miran "problems". Problems have not diminished desplte several different PHO postings. Obviously, there is considerable attention focused on Miran.

Dr. M. Niyazi is the latest PHO posted to Miran. He has had a reasonable record. He is given some hope of promotion to rank 3 and some imediate monetary gains, but he has to make his mark. Otherwise, he could acquire a bad record at Miran hurting his career in the MOPH. What should he do? How should he go about his job?

The Miran (B) case describes what Dr. Niyazi did, the reactions of the staff and the Ministry offictals, Dr. Niyazi's personal style and bellefs, and the results.

\section{Teaching Objectives}

(1) Improve participant understanding of their roles and relations with MOPH officials and external offices

(2) Sensitize the participants to the information sources of Ministry officials and their implications to the PHO.

(3) Enable participants to put their own minds/personalities into the situation and develop an understanding of the assumptions they make about others -- staff, supervisors and Governor.

(4) Develop toanagerial skills in handing a provincial hospital - separating the controllable and uncontrollable factors in budgets, In personnel, and handling each category differently.

The Miran (A) case is an open-ended case. Its chlef advantage is that it lets each participant develop his own plan of action, which he could compare with Dr. Niyazi's. The (A) case enables thinking through in unstructured situations so that participants spell out their plans, assunptions and expectations. During the class discussion, the instructor should identify among participants two or three prototypes of PHOs and action plans. Preparing an action plan could be a written assignnent to the participants. The assignnent could be a hone assignment, either before 
or after the class discussion of the (A) case. If the (A) case is used as an assignment, the (B) case should not be handed out before the partic1pants have had a chance to articulate their own plans approaches based on $(A)$, and arrived at their own bench rarks for evaluating the approach of $D r$. Niyazi described in the (B) case. If the $(A)$ and $(B)$ cases are handed out at the same time, then participant thinking may be eclipsed by what $D r$. Niyazi did. An attempt should be made to separate the two during in-class discussion, even if the two cases are handed out together.

\section{Discussion Questions}

\section{(A) Case:}

(1) What would you, as Dr. Niyazi, do?

(2) What asoumptions are you making regarding other people (doctors, nurses, staff, Governor, Ministry officials)? What responses do you expect?

(3) How would you go about drawing up a plan of action?

(4) What are the various authorities expecting from you, as PHO?

(5) How much time do you have?

(6) What priorities would you establish?

(7) What resources/variables are under your control? What are not?

(8) Whose support can you expect?

Depending on the responses of the participants, the instructor has to wold the class discussion so as to sensitize the participants to the difference in actors, Information sources and channels and their power, If some of the participant answers are insensitive to these while others are good, a dialogue between the two points of view would throw considerable light on the arguments, merits and demerits of each approach.

While there is no one correct approach, the participants can be helped to see alternative styles - participative, authoritarian, consultative, the situations and groups with which each style may work, and the problems with each style.

\section{Discussion Questions}

\section{(B) Case}

(1) What is your evaluation of Dr. Niyazi?

(2) What factors have helped him?

(3) What attitude has Dr. Niyaz1 adopted towards doctors, staff; Governor, Presidents?

(4) How can you conceptualize the job of a PHO?

(5) How can Dr. Niyazi, the Ministry ensure that improvements, If any, in the systems are sustained? 
(6) What are the similartties and differences between your approach (evolved after reading case $A$ ) and Dr. Niyazi's?

(7) What similarities and differences do you see in the approaches and personalities of Dr. Niyazi and Dr. Mahmud of Kataghan?

\section{Discussion Notes}

Dr. Niyazi is aware of the special importance being given to Miran. He knows that he has a short time to demonstrate that things are changing for the better at Miran. He can get reasonable help from the Governor and the Ministry in his efforts. For sustained support, he has to move fast and show results.

Dr. Niyazi has gone about his job with a "vision" of what he wants Miran Hospital to look like. He has used this to guide him in his work. He has worked within the structure and regulations governing the Provincial Hospitals, but he has used everything within his control. Ilis approach to the doctors is colleglal. He has enlisted their support through discussions and meetings. His approach to the Governor appears to be one of total cooperation. Dr. Niyazi has comunicated to the Governor his plans, the steps he has taken, the progress and problems. He also has taken interest in the broader health administrative aspects of Miran. He has quickly responded to the problem at the Woleswall and appears to have gained the Governor's confidence. To his employees, he has communicated clearly what he expects of them. He supervises and follows up the results. He has sent doctors to follow up in both Kabul and the Woleswali. He has sought the help of the deputy PHO In visiting the BHC. He appears to be clear in his mind that impressions have to be created at Kabul and at Miran and complaints have to be stopped.

Readings: Approprlate readings would be excerpts from Henry Mintzberg, The Nature of Managerial Work, or Seymour Tilles" article on the Manager " 8 $\mathrm{Job}$ in the Harvard Business Review, or the section on Kibutzer's World in Ansoft, et.al. (Eds.), in From Strategic Planning to Strateglc Management. If internal organizational management is the focus, readings could be taken from Edgar Schein, Organizational Psychology, Learitt (Ed,), Readings in Managerial Psychology; or Dairs, Human Behavior in Organizations. 